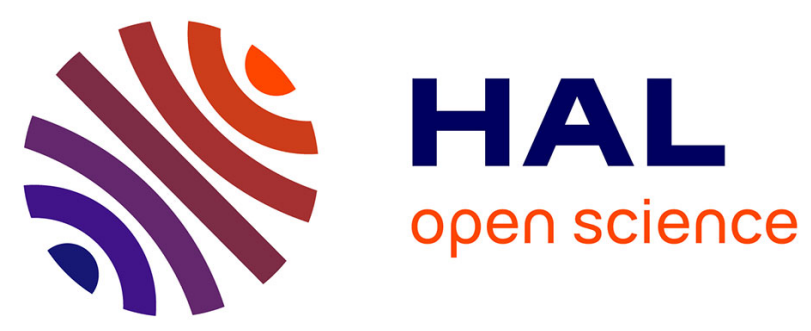

\title{
New intertidal crickets from Comoros and Mascarene islands (Orthoptera: Trigonidiidae: Nemobiinae: Burcini)
}

\author{
Sylvain Hugel, Laure Desutter-Grandcolas
}

\section{To cite this version:}

Sylvain Hugel, Laure Desutter-Grandcolas. New intertidal crickets from Comoros and Mascarene islands (Orthoptera: Trigonidiidae: Nemobiinae: Burcini). Zootaxa, 2021, 4995 (1), pp.1-26. 10.11646/zootaxa.4995.1.1. hal-03275537

\section{HAL Id: hal-03275537 https://hal.sorbonne-universite.fr/hal-03275537}

Submitted on 1 Jul 2021

HAL is a multi-disciplinary open access archive for the deposit and dissemination of scientific research documents, whether they are published or not. The documents may come from teaching and research institutions in France or abroad, or from public or private research centers.
L'archive ouverte pluridisciplinaire HAL, est destinée au dépôt et à la diffusion de documents scientifiques de niveau recherche, publiés ou non, émanant des établissements d'enseignement et de recherche français ou étrangers, des laboratoires publics ou privés. 
New intertidal crickets from Comoros and Mascarene islands (Orthoptera: Trigonidiidae: Nemobiinae: Burcini)

SYLVAIN HUGEL ${ }^{1}$ \& LAURE DESUTTER-GRANDCOLAS ${ }^{2}$

${ }^{1} \mathrm{INCl}$, UPR 3212 CNRS, Université de Strasbourg; 8 allée du Général Rouvillois; F-67084 Strasbourg.

E-mail: hugels@inci-cnrs.unistra.fr

${ }^{2}$ Institut de Systématique, Evolution et Biodiversité, Muséum national d'Histoire naturelle, CNRS, Sorbonne Université, EPHE, Université des Antilles, Case postale 50 (Entomologie), 57 rue Cuvier, F-75231 Paris cedex 05, France.

E-mail: laure.desutter-grandcolas@mnhn.fr

\begin{abstract}
Nemobiinae crickets of the tribe Burcini Gorochov, 1986 are described for the first time from the shores of South Western Indian Ocean islands. The new genus Makalapobius n. gen. is proposed to include $M$. aigrettensis n. gen. n. sp. from Mauritius and M. masihu n. gen. n. sp. from Grande Comore, and the new genus Gabusibius n. gen. to include G. ndzilu n. gen. n. sp. from Anjouan, G. mosi n. gen. n. sp., from Mohéli, and G. dzindzanu n. gen. n. sp. from Mayotte. The species Speonemobius littoreus Vannini \& Chelazzi, 1978 from Somalia coast is tentatively placed in the genus Gabusibius n. gen. as G. ? litoreus (Vannini \& Chelazzi, 1978) n. gen. n. comb. The songs of $G$. mosi n. gen. n. sp. and $M$. aigrettensis n. gen. n. sp. are described. The threats to SWIO Burcini and endemism of Orthoptera from SWIO coastal areas are discussed.
\end{abstract}

Key words: Endemism; intertidal species; taxonomy, distribution, new species, Orthoptera, Nemobiinae

\title{
Résumé
}

Des grillons Nemobiinae de la tribu des Burcini Gorochov, 1986 sont décrits pour la première fois des côtes des îles du sud-ouest de l'Océan Indien. Le nouveau genre Makalapobius n. gen. est proposé pour inclure $M$. aigrettensis n. gen. n. sp. de l'île Maurice et M. masihu n. gen. $\mathrm{n}$. sp. de Grande Comore, et le nouveau genre Gabusibius n. gen. pour inclure G. ndzilu n. gen. n. sp. d'Anjouan, G. mosi n. gen. n. sp., de Mohéli, et G. dzindzanu n. gen. n. sp. de Mayotte. L'espèce Speonemobius littoreus Vannini \& Chelazzi, 1978 de la côte somalienne est provisoirement placée dans le genre Gabusibius n. gen. en tant que G. ? litoreus (Vannini \& Chelazzi, 1978) n. gen. n. comb. Les chants de G. mosi n. gen. n. sp. et M. aigrettensis n. gen. n. sp. sont décrits. Les menaces s'exerçant sur les Burcini des îles du sud-ouest de l'Océan Indien, et l'endémisme des orthoptères des milieux côtiers de ces îles sont discutés.

\section{Introduction}

Together with Marinemobiini Gorochov, 1985, Burcini Gorochov, 1986 Nemobiinae live mostly on or near the shore, often in the intertidal habitats. Both tribes occur on Oriental, Australian, eastern Palearctic and Pacific regions (Cigliano et al. 2021; Gorochov, 1986; Gorochov et al. 2018; Otte \& Alexander, 1983). One single species has been described from the Eastern coast of continental Africa (Speonemobius litoreus Vannini and Chelazzi, 1978) as belonging to Speonemobius Chopard, 1924, a genus that was later proposed to be moved to Burcini 
(Gorochov et al. 2018). Except for this latter species, no Burcini was known from Africa nor from South Western Indian Ocean (SWIO) islands. During the surveys of Orthoptera on Mascarene islands (SH) and on Comoros (LDG and SH), we discovered new species of Burcini which are described in the present article.

\section{Material and methods}

Specimens examined. The new taxa are described based on specimens collected over the last decade by SH on Mauritius and by SH and LDG on Comoros. Specimens were collected at night or dusk by sight using a headlamp and a net. Specimens from caves were collected by day using similar techniques.

Abbreviations and symbols for taxonomic results. Male genitalia: Genitalic structures follow Desutter (1987) and Desutter-Grandcolas (2003): en. s., endophallic sclerite; gl., paired glands of ejaculatory duct; IEE, epi-ectophallic invagination; ps., pseudepiphallic sclerite; r., ramus. General morphology: Movable and articulated outgrowths are called spurs whereas immovable outgrowths are called spines (e.g. Otte \& Alexander, 1983; Jin \& Kevan, 1992; Rentz, 1985).

Abbreviations: I, II, III, anterior, median, posterior (leg, tibia femur, tarsomere); ai1, 2, 3, tibial inner apical spur 1, 2 or 3; ao1, 2, 3, tibial outer apical spur; ai/o, inner/outer TIII apical spur; DD, LL, dorsal disc, lateral lobe of pronotum; sai1, 2, 3, tibial inner subapical spur 1, 2 or 3; sao1, 2, 3, tibial outer subapical spur; SGP, subgenital plate.

Measurements (in $\mathrm{mm}$ ): BL, body length; PrnL, pronotum length (dorsal view); PrnW, pronotum width (dorsal view); FWL, fore wing length; FIL, FIIL, FIIIL, length of femora I, II, III, respectively; FIIIw, maximal width of FIII; OvpL, length of ovipositor.

Song recordings and analysis. Recordings have been performed with an Audiotechnica AT822 stereo microphone, on a HDR HC1E Sony camcorder (sampling rate: $48 \mathrm{kHz}$ ) on the nightshot mode (to follow the insect behavior) or using a Field memory recorder Fostex FR-2LE (sampling rate: $48 \mathrm{kHz}$, stereo) with a Seinnheiser K6/ME62 microphone (frequency range: $20-20 \mathrm{kHz} \pm$ $2.5 \mathrm{~dB}$ ). Song analysis has been performed with Clampfit 10.2 software. Song recordings are deposited in both S.H. and MNHN acoustic databases. Acoustic terminology is from Stumpner et al. (2013). All recordings were performed in natura at ambient temperature. The first harmonic (fundamental) is the only carrier frequency given in the text; the recording device used in the field usually does not allow defining whether it corresponds to the dominant frequency.

Geographic names. In the present article, Comoros is used as a geographic name matter apart from any political consideration.

Repository. BMNH, The Natural History Museum, London (formerly British Museum of Natural History); MNHN, Muséum national d'Histoire naturelle, Paris; coll. SH: collection Sylvain Hugel, Strasbourg, France.

Databases and inventory numbers. The codes following specimen data correspond to the specimen numbers from SH or LDG field pad. Specimens deposited in the MNHN collections 
have a unique inventory number, MNHN-EO-ENSIFXXXX, and can be found in the collection data base of the MNHN at the following address, https:// science.mnhn.fr/institution/mnhn/collection/eo/search

\section{Results}

List of studied taxa:

Tribe Burcini Gorochov, 1986

Genus Makalapobius n. gen.

M. aigrettensis n. gen. n. sp. [Mauritius - lle Maurice]

M. masihu n. gen. n. sp. [Ngazidja - Grande Comore]

Genus Gabusibius n. gen.

G. ndzilu n. gen. n. sp. [Ndzuani - Anjouan]

G. mosi n. gen. n. sp. [Mwali - Mohéli]

G. dzindzanu n. gen. n. sp. [Maore-Mayotte]

G. ? litoreus (Vannini \& Chelazzi, 1978) n. gen. n. comb. [Somalia]

\section{Etymology}

The two new genera described in the present work are named after local traditional musical instruments which are both threatened with extinction. Makalapo is a long curved stick planted into the ground which is connected by a string to a sound box buried in the ground; it was traditionally used to play Sega in Mauritius. Gabusi is a short-necked lute similar to Qanbūs; it was widespread on Comoros. The name aigrettensis is derived from the type locality lle aux Aigrettes, an islet managed by Mauritian Wildlife Foundation. New Comorian species belonging to Gabusibius n. gen. and Makalapobius n. gen. are named after words in Comorian: masihu means night, ndzilu means black, mosi means grey and dzindzanu means yellow.

\section{Makalapobius n. gen.}

(Figs. 1-24; 71-72; 77)

Type species. Malakapobius aigrettensis n. gen., n. sp., here designated.

Species included. Malakapobius n. gen. includes Malakapobius aigrettensis n. gen., n. sp. and Malakapobius masihu n. gen. n. sp..

Distribution. South Western Indian Ocean: Mascarene islands, Mauritius; Comoros, Ngazidja (Grande Comore).

Diagnosis. Makalapobius n. gen. is superficially similar to Burcus Gorochov, 1986, to Paraburcus Gorochov, 2018, and to Gabusibius n. gen. It is characterized by the following characters. TIII with 2 sai (Fig. 5; unlike Neoburcus Gorochov, 2018 which has 3 sai). Male winged (Fig. 1; unlike Taiwanemobius Yang \& Chang, 1996); with distinct stridulum (Fig. 7; unlike Paranemobius Saussure, 1877); wings oval, truncated (Fig. 1; unlike Burcus Gorochov, 1986 with relatively long FW); without mirror (Fig. 7; unlike Speonemobius Chopard, 1924 with full mirror); with relatively long diagonal vein (Fig. 7; unlike Paraburcus with short diagonal 
vein). Male SGP trilobated (Figs. 6, 15); median lobe small, membranous, not longer than lateral lobes (unlike Burcus with only one single median lobe). Male genitalia (Figs. 19-24: pseudepiphallus lightly curved upwards distally (curved downwards in Paraburcus, strongly upcurved from the middle in Burcus); apex narrow in side view (unlike Gabusibius n. gen. with very wide apex in side view); apex with rounded distal lophi relatively contiguous; without apical lateral extensions forming large apical concavity visible dorsally (unlike most Burcus species). Epi-ectophallic invagination not extending more anteriorly than rami insertion (unlike Burcus and Gabusibius n. gen. with long epi-ectophallic invagination exceeding rami insertion); rami very wide in side view (unlike all other genera except Gabusibius n. gen.).

Description. Including characters shared by other Burcini.

Burcini of average size. General coloration typical for Burcini, from light grey to light yellowish, with numerous black patterns. Head, pronotum and femora with long black bristles (Figs. 13).

Head. Not wider than pronotum (Figs. 1, 12). Antennae dark, unbanded. Eyes moderately protruding, not flattened on head dorsum (Figs. 1-3, 12-13). Ocelli small; lateral ocelli rounded, well distinct; median ocellus less distinct, localized dorsally to fastigium tip; distance between lateral ocelli larger than distance between one lateral ocellus and median ocellus. Fastigium between antennae not wider that scapes (Figs. 3, 13); scapes wider than high (front view); palpi short, article length: $5>3>4$; article 5 apex strongly widened.

Thorax. Pronotum (Figs. 1-2, 12) wider than long, 0.65-0.70 times as long as wide; DD sides subparallel, DD slightly narrower anteriorly, slightly enlarged before mid-length; DD anterior margin inconspicuously concave; DD posterior margin weakly rounded; DD longitudinal median furrow weakly imprinted; DD anterior transverse furrow distinct on the sides; LL shallow, higher anteriorly, less high posteriorly.

Legs. Legs of average size for Burcini, not elongated. TI with long narrowly oval outer tympanum; without inner tympanum. TI and TII with 2 ventral apical spurs, the inner the longest. FIII not particularly widened nor narrow (Figs. 4, 14): ca. 3.0-3.3 times as long as wide. TIII apical spurs typical of burcini (Figs. 4-5): 3 ao, 2 ai; relative length of apical spurs: ao2>ao3>ao1, ai2>ai1. TIII with 3 outer and 2 inner subapical spurs; relative length of subapical spurs: sao1=sao2>sao3, sai1>sai2. Hind tarsi long, particularly hind basitarsi. Hind basitarsi without dorsal serration (as usual in Nemobiini, see Desutter-Grandcolas et al. submit.); with 3 apical spurs: 2 dorsal apical spurs, the inner very small, 1 inner ventral apical spur longer than the dorsal outer one.

Wings. FW (Figs. 71, 72) present in males, absent in females. HW absent in both sexes.

Coloration. Head (Figs. 1-3, 12-13): Face with black patterns below the eyes converging to clypeus; semicircular area below antennae black; face black patterns surrounding a light yellow triangle pointing upwards; mandibles light yellow; scapes light yellow, antennae darker than scapes, not banded; palpi light yellow; genae light yellow; tip of fastigium black dorsally; semicircular area dorsal to antennae with dark pattern; occiput dark yellow. Thorax (Figs. 1-2, 12): Pronotum color variable, DD light yellow with black lateral spots near anterior margin or very dark with two light lateral spots near anterior margin; LL black, anterior ventral margin light yellow. Abdomen dark with or without light yellow spots. Legs (Figs. 4-5, 14): yellow or light yellow with darker bandings; FIII lateral side with dark basis, with 3 transverse dark bandings; TIII dark.

Male. Wings. FW (Fig. 1, 7, 12, 16) oval in shape, truncated apically. Stridulatory apparatus well developed, with relatively long diagonal vein; with well distinct chords, relatively long for 
Burcini; without a mirror: FW distal part with reticulation (Fig. 7). Subgenital plate. Apex trilobated (Fig. 6), median lobe small, membranous, not longer than lateral lobes. Genitalia (Figs. 19-24). Pseudepiphallus narrow in dorsal view and side view, elongated, lightly curved upwards (sideview); apex with rounded distal lophi; without apical lateral extensions; without large apical concavity visible dorsally. Apodemes absent. Epi-ectophallic invagination not extending more anteriorly than rami insertion. Rami very wide (side view).

Female. No trace of wings (Figs. 18, 72). Subgenital plate (Fig. 8) trapezoidal. Ovipositor weakly up curved; weakly enlarged apically (Fig. 17). Genitalia. Copulatory papilla not examined.

Calling song. When known, male call is made of verses of increasing amplitude lasting more than 1 second (Fig. 9-11).

\section{Makalapobius aigrettensis $\mathrm{n}$. gen. $\mathrm{n}$. sp.}

(Figs. 1-11; 19-21; 71-72; 77; Tab. 1)

Makalapobius aigrettensis n. gen. n. sp., here described.

Distribution: South Western Indian Ocean, Mascarene Islands, Mauritius.

Holotype. Male. Ile Maurice, Ile aux Aigrettes, plage, -20.4190, 57.7302, 0.3m; 10.V.2009; S. Hugel leg. (2011MauRodSH 059), MNHN (MNHN-EO-ENSIF12130).

Allotype. Female. Same as Holotype; S. Hugel leg. (2011MauRodSH 064), MNHN (MNHN-EOENSIF12131).

Paratypes, 7 males, 6 females. $10^{\pi}$ Ile Maurice, lle aux Aigrettes, plage, -20.4190, 57.7302, 0.3m; 10.V.2009; S. Hugel leg. (BIOTAS 2009 271), Coll. SH. 1 ㅇ Ile Maurice, lle aux Aigrettes, plage, -20.4190, 57.7302, 0.3m; 10.V.2009; S. Hugel leg. (BIOTAS 2009 224), Coll. SH. $10^{\text {I Ile }}$ Maurice, Ile aux Aigrettes, plage, -20.4190, 57.7302, 0.3m; 10.V.2009; S. Hugel leg. (2011MauRodSH 058), MNHN (MNHN-EO-ENSIF12132). 1 o' lle Maurice, lle aux Aigrettes, plage, -20.4190, 57.7302, 0.3m; 10.V.2009; S. Hugel leg. (2011MauRodSH 060), Coll. SH. 1 o" Ile Maurice, Ile aux Aigrettes, plage, -20.4190, 57.7302, 0.3m; 10.V.2009; S. Hugel leg. (2011MauRodSH 061), Coll. SH. 1 \& Ile Maurice, lle aux Aigrettes, plage, -20.4190, 57.7302, 0.3m; 10.V.2009; S. Hugel leg. (2011MauRodSH 062), MNHN (MNHN-EO-ENSIF12133). 1 I lle Maurice, Ile aux Aigrettes, plage, -20.4190, 57.7302, 0.3m; 10.V.2009; S. Hugel leg. (2011MauRodSH 063), Coll. SH. 1 \& lle Maurice, lle aux Aigrettes, plage, -20.4190, 57.7302,

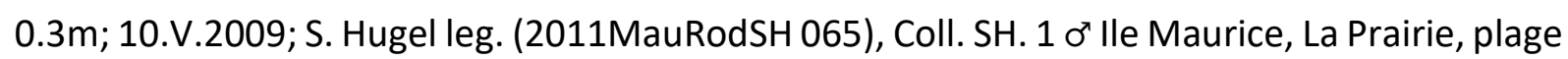
sous coraux, -20.4885, 57.3616, 0.5m; 28.IV.2011; S. Hugel leg. (2011MauRodSH 025), Coll. SH. (DNA sequences in Chintauan-Marquier et al. 2016 under the name Tethella sp_MAU, sample LDG150). 1 o' lle Maurice, La Prairie, plage sous coraux, -20.4885, 57.3616, 0.5m; 28.IV.2011; S. Hugel leg. (2011MauRodSH 026), Coll. SH. 1 \& lle Maurice, La Prairie, plage sous coraux, -20.4885, 57.3616, 0.5m; 28.IV.2011; S. Hugel leg. (2011MauRodSH 028), Coll. SH. 1 q Ile Maurice, La Prairie, plage sous coraux, -20.4885, 57.3616, 0.5m; 28.IV.2011; S. Hugel leg. (2011MauRodSH 027), Coll. SH. 1 o' lle Maurice, lle aux Aigrettes, grotte, -20.4187, 57.7304, 0.3m; 4.III.2008; S. Hugel leg. (BIOTAS2008 424), Recorded, Coll. SH.

Other specimens (non type material). 3 Juveniles. 1 juvenile, lle Maurice, lle aux Aigrettes, plage, -20.4190, 57.7302, 0.3m; 10.V.2009; S. Hugel leg. (BIOTAS 2009 272), Coll. SH. 1 juvenile, Ile Maurice, Ile aux Aigrettes, grotte, -20.4187, 57.7304, 0.3m; 4.III.2008; S. Hugel leg. 
(BIOTAS 2009 230), Coll. SH. 1 juvenile, Ile Maurice, lle aux Aigrettes, grotte, -20.4187, 57.7304, 0.3m; 4.III.2008; S. Hugel leg. (BIOTAS 2009 231), Coll. SH.

\section{Diagnosis.}

This species is characterized by its color: light with black patterns (very dark in M. masihu $\mathrm{n}$. gen. n. sp.); its relatively small size (BL $<9.5 \mathrm{~mm}$ vs. $>9.5$ in $M$. masihu n. gen. n. sp.); its male genitalia: pseudepiphallus relatively short in dorsal view and wide in side view for the genus; apical lophi rounded in side view (unlike M. masihu n. gen. n. sp. with longer and very narrow pseudepiphallus, and lophi regularly narrowed toward apex in side view).

Description. In addition to generic characters.

Color. Head (Figs. 1-3): Face with black patterns below the eyes converging to clypeus; semicircular area below antennae black; face black patterns surrounding a light yellow triangle pointing upwards; palpi light yellow; genae light yellow; tip of fastigium black dorsally; semicircular area dorsal to antennae with dark pattern; occiput dark yellow. Thorax (Figs. 12): Pronotum DD light yellow with black lateral spots near anterior margin; with two small posterior black spots near midline; LL black, anterior ventral margin light yellow. Abdomen dark with light yellow spots. Legs (Figs. 4-5): light with dark bandings; FIII lateral side with dark basis, with 3 transverse dark bandings; TIII darker than light parts of FIII.

Male. Wings. The two anterior-most chords delineating a long D-shaped cell. Stridulatory file with 51 teeth (paratype 2011MauRodSH 026). Subgenital plate. Apex trilobated: median lobe small, membranous; lateral lobes larger, rounded (Fig. 6). Genitalia (Figs. 19-21). Pseudepiphallus in dorsal view: narrow, distal half sub parallel; in side view: elongated, lightly curved upwards, with moderate enlargement near the apex at the upward bent, making it look like a hockey stick; apex with rounded contiguous distal lobes. Rami: very wide (side view), ventral margin linear; dorsal margin with two dorsal bumps. Female. SGP (Fig. 8) hind margin shallowly concave. Ovipositor (Fig. 8) with a subapical gap between dorsal and ventral valves.

Song. The call of this species has been recorded by day hours in lle aux Aigrettes, in a small cave connected to the sea $\left(30^{\circ} \mathrm{C}\right.$; Figs. 9-11). The male was isolated with no other specimen nearby. The first harmonic of the call peaks at $6.1 \mathrm{kHz}$. The call consists in long syllables of increasing amplitude. Syllable duration: $4.2 \pm 0.2 \mathrm{~s}(3.9-4.4 \mathrm{~s})$; gap between syllables: $58 \pm 122 \mathrm{~s}$ (46-70 s).

Biology. The main habitat of this species is on lle aux Aigrettes, and islet formed from corallimestone localized $1 \mathrm{~km}$ East of Mauritius and declared nature reserve since 1965. This islet is managed by the Mauritian Wildlife Foundation (MWF). Most of the islet shore corresponds to small cliffs, often very concave, with numerous cracks and holes. At $10 \mathrm{~m}$ from the shore, the small cave is connected to the sea and smaller caves or faults connected to the sea seem to occur elsewhere on the islet. At low tide, a few small sand beaches or limestone rocky beaches emerge. Makalapobius aigrettensis $\mathrm{n}$. gen. $\mathrm{n}$. sp. occurs on all these sea-connected habitats, hiding on cracks and holes of the cliffs at high tide, and going out at night, particularly at low tide. By day hours, the discreet call of Makalapobius aigrettensis n. gen. $\mathrm{n}$. sp. can be heard from the islet cliffs when approaching the shore from the sea. We also found this species 
on large pebble beach in the South of Mauritius (in La Prairie), and observed it on the shore of Bambou Virieux, but at very low density.

The population of this remarkable species appears to have been directly impacted by the ecological disaster caused in August 2020 by the sinking of the tanker Wakashio. Despite searching, the species could not be found until February 2021 when a few specimens were observed again by Sooraj Dwarika (MWF).

TABLE 1. Measurements of Makalapobius aigrettensis n. gen. n. sp. (in mm).

\begin{tabular}{|c|c|c|c|c|c|c|c|c|c|}
\hline & $\mathrm{BL}$ & PrnL & PrnW & FWL & FIL & FIIL & FIIIL & FIIIW & OvpL \\
\hline$\sigma^{\top}$ Holotype & 7.75 & 1.50 & 2.15 & 2.50 & 2.75 & 2.80 & 5.15 & 2.40 & \\
\hline @ Allotype & 8.35 & 1.70 & 2.55 & - & 2.65 & 2.90 & 6.00 & 1.80 & 5.00 \\
\hline \multicolumn{10}{|l|}{$0^{\prime \prime} 0^{\prime \prime}$} \\
\hline Average & 7.89 & 1.53 & 2.22 & 2.31 & 2.73 & 2.68 & 5.24 & 1.88 & - \\
\hline Min & 7.60 & 1.50 & 2.10 & 2.15 & 2.50 & 2.60 & 5.10 & 1.55 & - \\
\hline Max & 8.50 & 1.60 & 2.40 & 2.50 & 2.85 & 2.80 & 5.40 & 2.40 & - \\
\hline \multicolumn{10}{|l|}{ фо } \\
\hline Average & 8.77 & 1.70 & 2.50 & - & 2.82 & 3.03 & 5.97 & 1.78 & 4.82 \\
\hline Min & 8.35 & 1.60 & 2.40 & - & 2.65 & 2.90 & 5.80 & 1.70 & 4.70 \\
\hline Max & 9.30 & 1.80 & 2.55 & - & 2.90 & 3.20 & 6.10 & 1.85 & 5.00 \\
\hline
\end{tabular}

Makalapobius masihu n. gen. n. sp.

(Figs. 12-18; 22-24; 77; Tab. 2)

Makalapobius masihu n. gen. n. sp., here described.

Holotype. Male. Comores, Grande Comores, Moroni, Itsandra, plage de galets, de sable et de corail, S11 $41^{\prime}$ 04" E043¹5'40"; 21.VIII.2010; S. Hugel \& L. Desutter-Grandcolas leg. (LDG295), MNHN (MNHN-EO-ENSIF12147).

Allotype. Female. Comores, Grande Comores, Moroni, Itsandra, plage de galets, de sable et

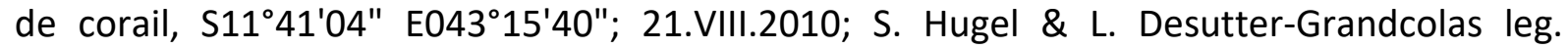
(LDG296), MNHN (MNHN-EO-ENSIF12148).

Other specimens (non type material). 1 juvenile, same as the holotype, S. Hugel \& L. DesutterGrandcolas leg. (LDG 297), MNHN.

Distribution. South Western Indian Ocean, Comoros, Ngazidja (Grande Comore).

\section{Diagnosis.}

This species is characterized by its color: very dark, particularly abdomen (light with dark patterns in $M$. aigrettensis n. gen. n. sp.); its relatively large size (BL $>9.5 \mathrm{~mm}$ vs. $<9.5$ in $M$. aigrettensis n. gen. n. sp.); its male genitalia: pseudepiphallus relatively long in dorsal view and narrow in side view for the genus; apical lophi regularly narrowed toward apex in side view (unlike $M$. aigrettensis n. gen. $\mathrm{n}$. sp. with shorter and less very narrow pseudepiphallus, and lophi rounded in side view). 
Description. In addition to generic characters

Color. Head (Figs 12-13): Face with black patterns below the eyes converging to clypeus; semicircular area below antennae black; face black patterns surrounding a light yellow triangle pointing upwards; palpi light yellow; genae light yellow; tip of fastigium black dorsally; semicircular area dorsal to antennae with dark pattern; occiput dark yellow. Thorax (Figs 1218): Pronotum DD very dark with two light lateral spots near anterior margin in male holotype (Fig. 12); DD light yellow with black lateral spots near anterior margin and with two small posterior black spots near midline in female allotype (Fig. 18); LL black, anterior ventral margin light yellow. Abdomen dark in male holotype, with few light spots in female allotype. Legs (Figs. 12, 14): yellow with dark bandings; FIII lateral side with dark basis, with 3 transverse dark bandings; TIII darker than light part of FIII.

Male. Wings. FW short and truncated straight. The two anterior-most chords delineating a short D-shaped cell (Fig. 16 arrow). Subgenital plate. Distorted in the only male available. Apex trilobated: median lobe less sclerotized but as high as the lateral lobes; lateral lobes more rounded (Fig. 15). Genitalia (Figs. 22-24). Pseudepiphallus in dorsal view: very narrow with parallel margins; in side view: very elongated, very lightly curved upwards, with clear enlargement near the apex at the upward bent; apex with rounded contiguous distal lobes. Rami: short and very wide (side view), ventral margin linear; dorsal margin with two very short dorsal bumps. Female. SGP hind margin shallowly concave, with a narrow median emargination. Ovipositor (Fig. 17) with a subapical gap between dorsal and ventral valves.

Table 2. Measurements of Makalapobius masihu n. gen. n. sp. (in mm).

\begin{tabular}{lccccccccc}
\hline & BL & PrnL & PrnW & FWL & FIL & FIIL & FIIIL & FIIIW & OvpL \\
\hline O' Holotype & 9.60 & 1.60 & 2.15 & 2.00 & 2.60 & 2.80 & 5.70 & 1.70 & - \\
9 Allotype & 9.80 & 1.75 & 2.35 & - & 2.30 & 2.45 & 5.50 & 1.85 & 5.00 \\
\hline
\end{tabular}

\section{Genus Gabusibius n. gen.}

(Figs. 25-70; 73-77)

Type species. Gabusibius mosi n. gen., n. sp, here designated.

Species included. G. ndzilu n. gen. n. sp.; G. mosi n. gen. n. sp.; G. dzindzanu n. gen. n. sp.. Speonemobius litoreus Vannini \& Chelazzi 1978 is tentatively placed in the genus Gabusibius n. gen. n. comb..

Distribution. South Western Indian Ocean, Comoros, possibly Somalia.

Diagnosis. Gabusibius n. gen. is superficially similar to Burcus Gorochov, 1986, to Paraburcus Gorochov, 2018, and to Malakapobius n. gen. It is characterized by the following characters. TIII with 2 sai (Figs. 25, 29; unlike Neoburcus Gorochov, 2018 which has 3 sai). Male winged (Figs. 25, 33, 49, 57; unlike Taiwanemobius Yang \& Chang, 1996); with distinct stridulum (Figs. 31, 40, 55, 60; unlike Paranemobius Saussure, 1877); wings oval, truncated (Fig. 25, 33, 49, 58; unlike Burcus with relatively long FW); without mirror (Figs. 31, 40, 55, 60; unlike 
Speonemobius Chopard, 1924 with full mirror); with relatively long diagonal vein (unlike Paraburcus with short diagonal vein). Male SGP with only one apical lobe (Figs. 30, 39, 54; unlike Malakapobius n. gen. with trilobated SGP, Figs. 6, 15), median lobe small, membranous. Male genitalia (Figs. 62-70: pseudepiphallus dorsal magin not curved or weakly curved upwards (unlike Paraburcus with epiphallus curved downwards, and unlike Malakapobius n. gen, Burcus, Neoburcus, with pseudepiphallus curved upwards); distal part of pseudepiphallus broad in side view (unlike Malakapobius $\mathrm{n}$. gen. with very narrow apex in side view); apex without rounded contiguous distal lobes (unlike Malakapobius n. gen.); without apical lateral extensions forming large apical concavity visible dorsally (unlike Burcus). Epi-ectophallic invagination extending more anteriorly than rami insertion (unlike Malakapobius $\mathrm{n}$. gen. with short epi-ectophallic invagination not exceeding rami insertion); rami very wide in side view (unlike all other genera except Malakapobiusn. gen.).

Description. Including characters shared by other Burcini.

Burcini of average size. General coloration typical for Burcini, from dark grey to light yellowish, with numerous black patterns. Head, pronotum and femora with long black bristles (Figs. 25, $33,49,58)$.

Head (Figs. 25, 33, 49, 58). Not wider than pronotum. Eyes moderately protruding, not flattened on head dorsum (Fig 1-3). Ocelli small; lateral ocelli rounded, well distinct; median ocellus less distinct, localized dorsally to fatigium tip; distance between lateral ocelli similar to distance between one lateral ocellus and median ocellus. Fastigium between antennae not wider that scapes; scapes wider than high (front view); palpi short, article length: 5>3>4; article 5 apex strongly widened.

Thorax (Figs. 25-26, 33-34, 49-50, 57-58). Pronotum wider than long, 0.61-0.72 times as long as wide; DD sides subparallel, DD slightly narrower anteriorly, slightly enlarged before midlength; DD anterior margin strait or weakly rounded; DD posterior margin weakly rounded; DD longitudinal median furrow imprinted anteriorly; DD anterior transverse furrow distinct on the sides; LL shallow, higher anteriorly, less high posteriorly.

Legs (Figs. 25, 29, 36, 38, 52, 53). Legs of average size for Burcini, not elongated. TI with long oval outer tympanum; without inner tympanum. TI and TII with 2 ventral apical spurs of same length. FIII not particularly widened nor narrow: ca. 2.8-3.9 times as long as wide. TIII apical spurs typical of burcini: 3 ao, 2 ai; relative length of apical spurs: ao2>ao3>ao1, ai2>ai1. TIII with 3 outer and 2 inner subapical spurs; relative length of subapical spurs: sao1>sao2>sao3, sai1>sai2. Hind tarsi long, particularly hind basitarsi. Hind basitarsi without dorsal serration (as usual in Nemobiini, see Desutter-Grandcolas et al. submit.); with 3 apical spurs: 2 dorsal apical spurs, the inner very small; 1 inner ventral apical spur longer than the dorsal outer one. Wings. FW (Figs. 73-76) present in males, absent in females. HW absent in both sexes.

Coloration. Head (Figs. 25-27; 33-35; 49-51; 57-59). Antennae dark, unbanded. Face with more or less extended black patterns below the eyes converging to clypeus; semicircular area below antennae with black pattern more or less extended; face black patterns surrounding a light yellow area, more or less extended and pointing upwards; mandibles of variable color; scapus usually light yellow, antennae dark, not banded; palpi light yellow; genae light; tip of fastigium black dorsally; area dorsal to antennae with dark patch of variable extent; occiput of variable color, from light yellow to dark. Thorax (Figs. 25-26, 33-34, 49-50, 57-58). Pronotum DD from light yellow to grey, with black or dark lateral spots near anterior margin; with two small posterior black spots near midline; LL dark or black, anterior ventral margin sometimes lighter. Abdomen dark with light yellow spots. Legs (Figs. 28-29; 36-38; 52-53; 57). 
Light yellow with dark bandings; FIII lateral field with dark basis, with 3 transverse dark bandings, the distal one on the knee; TIII dark.

Male. Wings. FW (Figs. 31, 40, 55, 60) oval in shape, truncated apically. Stridulatory apparatus well developed, with relatively long diagonal vein; with well distinct chords, not particularly long for Burcini; without mirror: FW distal part with reticulation. Subgenital plate. Apex with only a median membranous lobe (Figs. 30, 39, 54). Genitalia (Figs. 62-70). Pseudepiphallus wide in dorsal view and side view, elongated, not particularly curved upwards (side view); apex without rounded contiguous distal lobes; without apical lateral extensions; without large apical concavity visible dorsally. Apodemes absent. Epi-ectophallic invagination extending more anteriorly than rami insertion. Rami very wide (side view), truncated anteriorly.

Female. No trace of wings (Figs. 74, 76). Subgenital plate (Figs. 32, 41, 56, 61) trapezoidal. Ovipositor weakly up curved; weakly enlarged apically (Figs. 32, 41, 56, 61). Genitalia. Copulatory papilla not examined.

Calling song. Only known from the type species G. mosi n. gen. n. sp and from G. ? litoreus (Vannini \& Chelazzi) n. gen. n. comb. Male call is made of short verses of relatively constant amplitude and lasting less than 0.2 seconds (Figs. 42-48).

Remark on coloration. The only species observed on volcanic shingle beaches (Gabusibius ndzilu n. gen. n. sp.) is very dark as is its habitat, whereas species living on coral shores are lighter. It is not clear whether color corresponds to an inherited trait and a stable character allowing to distinguish species, or whether color is flexible and directly depending on the environment where juveniles have grown. Nevertheless, Gabusibius mosi n. gen. n. sp. known from various localities and numerous specimens displays conspicuous variation in the extent of the black patterns indicating that color is quite a variable character.

\section{Gabusibius ndzilu n. gen. n. sp.}

(Figs. 25-32; 62-64; 77; Tab. 3)

Gabusibius ndzilu n. gen. n. sp., here described.

Holotype. Male. Comores, Anjouan, Dar Salam, plage de galets, $-12.2533,44.3841,0.5 \mathrm{~m}$; 27.XI.2011; S. Hugel leg. (2010 COM SH 117), MNHN (MNHN-EO-ENSIF12134).

Allotype. Female. Same as Holotype; S. Hugel leg. (2010 COM SH 118), MNHN (MNHN-EOENSIF12135).

Paratypes, 29. 19, same as holotype; S. Hugel leg. (2010 COM SH 120), Coll. SH.; 19, same as holotype, S. Hugel leg. (2010 COM SH 119), Coll. SH.

Distribution. South Western Indian Ocean, Comoros, Ndzuani (Anjouan)

\section{Diagnosis.}

This species differs from all other species of Gabusibius n. gen. by its dark coloration (Figs. 2527), and male genitalia with spatulate pseudepiphallus (Figs. 62-64).

\section{Description.}

In addition to generic characters. Color. Species dark. Body background color dark grey with black patterns; light triangle on the face hardly visible, narrow between antennae. Legs background color light yellow, patterns very distinct and black. Male. Stridulatory file not 
examined. SGP (Fig. 30) larger than long (flattened). Genitalia (Figs. 62-64). Pseudepiphallus narrower in the middle, distal half spatulate with rounded ventral enlargement (dorsal view); dorsal margin slightly elevated distally (side view). Epi-ectophallic invagination exceeding moderately rami insertion and reaching anterior projection of endophallic sclerite (dorsal view). Rami very wide (side view), truncated anteriorly. Female. SGP hind margin shallowly concave (Fig. 32). OVP apex without distinct space between dorsal and ventral valves (Fig. 32).

Biology/Habitat. Gabusibius ndzilu n. gen. n. sp. lives on shingle beaches with large $(>10 \mathrm{~cm})$ volcanic round stones from the sea level to $1 \mathrm{~m}$ in elevation.

TABLE 3. Measurements of Gabusibius ndzilu n. gen. n. sp. (in mm).

\begin{tabular}{lccccccccc}
\hline & BL & PrnL & PrnW & FWL & FIL & FIIL & FIIIL & FIIIW & OvpL \\
\hline O' Holotype & 7.70 & 1.65 & 2.40 & 2.10 & 2.60 & 2.90 & 5.70 & 1.30 & \\
\& Allotype & 9.40 & 2.00 & 2.65 & & 2.85 & 2.80 & 6.10 & 1.80 & 5.00 \\
\& & & & & & & & & & \\
Average & 8.70 & 1.90 & 2.45 & & 2.78 & 2.80 & 6.20 & 1.73 & 4.83 \\
Min & 8.00 & 1.80 & 2.25 & & 2.70 & 2.80 & 6.10 & 1.65 & 4.65 \\
Max & 9.40 & 2.00 & 2.65 & & 2.85 & 2.80 & 6.30 & 1.80 & 5.00 \\
\hline
\end{tabular}

\section{Gabusibius mosi n. gen. n. sp.}

(Figs. 33-48; 65-67; 73-74; 77; Tab. 4)

Gabusibius mosi n. gen. n. sp., here described.

Holotype. Male. Comores, Mohéli, Chissioua Ouénéfou, plage de galets, -12.3924, 43.7072, 0.5m; 2.V.2010; S. Hugel leg. (Moheli.1 2010 098), MNHN (MNHN-EO-ENSIF12136).

Allotype. Female. Comores, Mohéli, Ouallah II, Miremani, plage, -12.3468, 43.6674, 0.5m; 24.VIII.2010; S. Hugel \& L. Desutter-Grandcolas leg. (2011 COM SH 187), MNHN (MNHN-EOENSIF12137).

Paratypes, 5o', 129. 10" same as holotype; S. Hugel leg. (Moheli.1 2010 097), Coll. SH. 19 same as holotype; S. Hugel leg. (Moheli.1 2010 099), Coll. SH.; 1ㅇ S. Hugel leg. (Moheli.1 2010 100), Coll. SH.; 1오 S. Hugel leg. (Moheli.1 2010 101), Coll. SH.; 19 S. Hugel leg. (Moheli.1 2010 102), Coll. SH.; 1ㅇ S. Hugel leg. (Moheli.1 2010 103), Coll. SH.; 19 S. Hugel leg. (Moheli.1 2010 104), Coll. SH. 10 Comores, Mohéli, Ouallah II, Miremani, plage, -12.3468, 43.6674, 0.5m; 24.VIII.2010; S. Hugel \& L. Desutter-Grandcolas leg. (2010 COM SH 186), Coll. SH; 19 same as

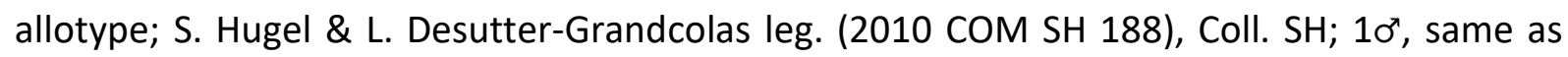
allotype, S. Hugel \& L. Desutter-Grandcolas leg. (LDG 338), in Chintauan-Marquier et al. 2016 molecular sampling LDG 028 as Tethella sp_Com, MNHN (MNHN-EO-ENSIF3313); 20', same as allotype, S. Hugel \& L. Desutter-Grandcolas leg. (LDG 339, LDG340), MNHN (MNHN-EOENSIF12138,12139); 5 9 same as allotype; S. Hugel \& L. Desutter-Grandcolas leg., (LDG342346), MNHN (MNHN-EO-ENSIF12140, 12141, 12142, 12143, 12144).

Other specimens (non type material). 3 specimens. 3 juveniles, same as the allotype, S. Hugel \& L. Desutter-Grandcolas leg. (LDG 341, LDG347, LDG 348), MNHN. 
Distribution. South Western Indian Ocean, Comoros, Mwali (Mohéli)

\section{Diagnosis.}

This species differs from Gabusibius ndzilu n. gen. n. sp. by its lighter color and from Gabusibius ? littoreus n. gen. n. comb. by the darker patterns. It differs from all Comorian species of Gabusibius n. gen. by male genitalia (Figs. 65-67): Pseudepiphallus with parallel sides converging in the last distal fifth; apex broadly rounded, not forming two lobes (dorsal view); apex not elevated distally (side view). Epi-ectophallic invagination exceeding anterior projection of endophallic sclerite; not spoon-shaped (unlike Gabusibius dzindzanu n. gen. n. sp.).

\section{Description.}

In addition to generic characters. Color. Species with light background and black patterns (Figs. 33-38). In holotype, body background color light yellow with black patterns; light triangle on the face distinct, with broad basis, narrow between antennae. Legs background color light yellow, patterns very distinct and black. Extent of black patterns variable on paratypes. Male. Stridulatory file with 56 teeth (holotype). SGP (Fig. 39) broader than long (flattened). Genitalia (Figs. 65-67). Pseudepiphallus with parallel sides converging in the last distal fifth; apex broadly rounded, not forming two lobes (dorsal view); apex not elevated distally (side view). Epi-ectophallic invagination exceeding anterior projection of endophallic sclerite; anterior part moderately concave, not spoon-shaped. Rami very wide (side view), truncated anteriorly. Female. SGP hind margin shallowly concave (Fig. 41). OVP apex without distinct space between dorsal and ventral valves (Fig. 41).

Song. The song has been recorded at $10 \mathrm{am}, 25^{\circ} \mathrm{C}$ in an open cave in the shore (Figs. 42-48). Two types of songs have been recorded simultaneously and specimens switched from one to the other song type. Calling specimens were not directly observed, it is, therefore, not possible to associate the song type with a peculiar behavior (courtship, call, etc.). The first harmonic of both songs peaks at 5.5-6.6 kHz. One type of song is made of verses organized in syllables made of pulses at high rate (Fig. 44, 5 verses): verses duration: 680 $\pm 869 \mathrm{~ms}$ (222-5177 ms), gap between verses: $633 \pm 113 \mathrm{~ms}$ (369-812 ms), number of syllables per verse: $4.6 \pm 5.3(2-33)$, syllable rate during verses: $162.1 \pm 17.9 \mathrm{~ms}(136.3-212.6 \mathrm{~ms})$, pulses during syllables: $3.3 \pm 0.5$ (3-4), pulse rate during syllables: $15.6 \pm 4.6 \mathrm{~ms}(9.1-24.9 \mathrm{~ms})$. The other type of song is made of verses not organized in syllables and made of pulses at low rate (Fig. 44, between $17.4 \mathrm{~ms}$ and $17.6 \mathrm{~ms})$ : verses duration: $116 \pm 40 \mathrm{~ms}(66-164 \mathrm{~ms})$, gap between verses: $905 \pm 431 \mathrm{~ms}(273-$ $1949 \mathrm{~ms}$ ), pulses during syllables: $6.5 \pm 0.9$ (5-8), pulse rate during syllables: $16.5 \pm 3.0 \mathrm{~ms}$ (10.0$19.0 \mathrm{~ms})$.

Biology. This species occurs on rocky beaches (mixed limestone and volcanic pebbles of small diameter). It can be observed by night hours, particularly at low tide. In Miremani, it can be observed by day hours in a shallow cave on the shore.

Table 4. Measurements of Gabusibius mosi n. gen. n. sp. (in mm).

\begin{tabular}{lccccccccc}
\hline & BL & PrnL & PrnW & FWL & FIL & FIIL & FIIIL & FIIIW & OvpL \\
\hline O' Holotype & 8.60 & 1.75 & 2.20 & - & 2.50 & 2.80 & 5.70 & 1.65 & - \\
o Allotype & 9.60 & 1.75 & 2.50 & - & 2.60 & 2.75 & 5.50 & 1.70 & 4.60 \\
\hline
\end{tabular}




\begin{tabular}{|c|c|c|c|c|c|c|c|c|c|}
\hline Average & 8.70 & 1.58 & 2.28 & 2.28 & 2.53 & 2.60 & 5.47 & 1.47 & - \\
\hline Min & 8.40 & 1.50 & 2.20 & 2.25 & 2.50 & 2.40 & 5.30 & 1.35 & - \\
\hline Max & 9.10 & 1.75 & 2.45 & 2.30 & 2.60 & 2.80 & 5.70 & 1.65 & - \\
\hline \multicolumn{10}{|l|}{ १९ } \\
\hline Average & 8.80 & 1.77 & 2.53 & - & 2.65 & 2.72 & 5.73 & 1.67 & 4.58 \\
\hline Min & 7.60 & 1.70 & 2.30 & - & 2.60 & 2.60 & 5.50 & 1.50 & 4.50 \\
\hline Max & 9.60 & 1.85 & 2.80 & - & 2.70 & 2.80 & 6.10 & 1.80 & 4.65 \\
\hline
\end{tabular}

\section{Gabusibius dzindzanu n. gen. n. sp.}

(Figs. 49-56; 68-70; 75-77; Tab. 5)

Gabusibius dzindzanu n. gen. n. sp., here described.

Holotype. Male. Mayotte, Bandrele, Saziley Be, plage, -12.9746, 45.2016, 0.5m; 7.V.2010; S. Hugel leg. (Mayotte.1 2010 136), MNHN (MNHN-EO-ENSIF12145).

Allotype. Female. Same as Holotype; S. Hugel leg. (Mayotte.1 2010 138), MNHN (MNHN-EOENSIF12146).

Paratypes, 5o', 29. 10" same as holotype; S. Hugel leg. (Mayotte.1 2010 135), Coll. SH.; $10^{\top}$ S. Hugel leg. (Mayotte.1 2010 131), Coll. SH.; 10' S. Hugel leg. (Mayotte.1 2010 132), Coll. SH.; 10’ S. Hugel leg. (Mayotte.1 2010 133), Coll. SH.; 10` S. Hugel leg. (Mayotte.1 2010 134), Coll. SH. 19 same as holotype; S. Hugel leg. (Mayotte.1 2010 137), Coll. SH.; 19 S. Hugel leg. (Mayotte.1 2010 139), Coll. SH.

Other specimens (non type material). 1 juvenile same as holotype; S. Hugel leg. (Mayotte.1 2010 130), Coll. SH.

Distribution. South Western Indian Ocean, Comoros, Maore (Mayotte)

\section{Diagnosis.}

This species differs from Gabusibius ndzilu n. gen. n. sp. by its lighter color and from Gabusibius ? littoreus n. gen. n. comb. by the darker patterns. It differs from all Comorian species of Gabusibius n. gen. by male genitalia (Figs. 68-70). Pseudepiphallus with parallel sides in the anterior half, converging in the last distal half; apex with a shallow notch separating two lobes (dorsal view); apex not elevated distally (side view). Epi-ectophallic invagination exceeding anterior projection of endophallic sclerite distinctly spoon-shaped (unlike Gabusibius ndzilu n. gen. n. sp.).

\section{Description.}

In addition to generic characters. Color. Species with light background and black patterns (Figs. 49-53). Body background color light yellow with black patterns; light triangle on the face distinct, with broad basis, narrow between antennae. Legs background color light yellow, patterns very distinct and black. Male. Stridulatory file with 52 teeth (paratype Mayotte.1 2010 135). SGP (Fig. 54) broader than long (flattened). Genitalia (Figs. 68-70). Pseudepiphallus with parallel sides converging in the last distal fifth; apex broadly rounded, not forming two lobes (dorsal view); apex not elevated distally (side view). Epi-ectophallic invagination exceeding anterior projection of endophallic sclerite; anterior part moderately concave, not spoon-shaped. Rami squared, very wide (side view), truncated anteriorly. Female. SGP hind 
margin with V-shaped emargination (Fig. 56). OVP apex without narrow space between dorsal and ventral valves (Fig. 56).

Biology. This species occurs on rocky beaches (mixed limestone and volcanic pebbles of small diameter). It can be observed by night hours, particularly at low tide.

Table 5. Measurements of Gabusibius dzindzanu n. gen. n. sp. (in mm).

\begin{tabular}{lccccccccc}
\hline & BL & PrnL & PrnW & FWL & FIL & FIIL & FIIIL & FIIIW & OvpL \\
\hline Ơ Holotype & 8.00 & 1.70 & 2.30 & 2.30 & 2.80 & 2.60 & 5.90 & 1.80 & - \\
९ Allotype & 7.30 & 1.50 & 2.40 & & 2.70 & 2.60 & 5.70 & 1.70 & 4.20 \\
O'o & & & & & & & & & \\
Average & 7.89 & 1.64 & 2.18 & 1.98 & 2.70 & 2.68 & 5.59 & 1.81 & - \\
Min & 7.60 & 1.60 & 2.10 & 1.80 & 2.65 & 2.55 & 5.40 & 1.75 & - \\
Max & 8.25 & 1.70 & 2.30 & 2.30 & 2.80 & 2.80 & 5.90 & 1.90 & - \\
क̊ & & & & & & & & & \\
Average & 7.45 & 1.63 & 2.40 & - & 2.70 & 2.65 & 5.55 & 2.05 & 4.40 \\
Min & 7.30 & 1.50 & 2.40 & - & 2.70 & 2.60 & 5.40 & 1.70 & 4.20 \\
Max & 7.60 & 1.75 & 2.40 & - & 2.70 & 2.70 & 5.70 & 2.40 & 4.50 \\
\hline
\end{tabular}

Gabusibius ? litoreus (Vannini \& Chelazzi, 1978) n. gen. n. comb.

(Figs. 57-61; Tab. 6)

Speonemobius litoreus Vannini \& Chelazzi, 1978. Monitore Zoologico Italiano. (N.S.) Supplemento 11(1):2

Distribution. Africa, Northeast Tropical Africa, Somalia, Sar Uanle cliff (type locality)

Material examined: Male and female paratypes from Museo Zoologico of the University of

Florence.

Description complement.

Measurements, missing from original description are given (Table 5).

Female SGP distal margin with a deep V-shaped emargination (Fig. 61).

Remark. The habitat of this species has been comprehensively described by Vannini \& Chelazzi (1978). This habitat is strikingly similar to the type locality of Malakapobius aigrettensis $\mathrm{n}$. gen., n. sp. This remarkable publication also provides the first record of the song from a Burcini which is similar to the song of Gabusibius ndzilu n. gen. n. sp. (Figs. 28-34).

Table 6. Measurements of Gabusibius ? litoreus (Vannini \& Chelazzi, 1978) n. gen. n. comb. (in $\mathrm{mm})$.

\begin{tabular}{lccccccccc}
\hline & BL & PrnL & PrnW & FWL & FIL & FIIL & FIIIL & FIIIW & OvpL \\
\hline O' Paratypes $(\mathrm{n}=2)$ & 8.55 & 1.83 & 2.53 & 2.10 & 2.73 & 2.85 & 5.90 & 1.55 & - \\
9 Paratypes $(\mathrm{n}=2)$ & 8.00 & 1.80 & 2.25 & - & 2.70 & 2.80 & 6.30 & 1.65 & 4.65 \\
\hline
\end{tabular}

Remarks on Speonemobius Chopard, 1924 
Eight species are currently considered as belonging to Speonemobius Chopard, 1924. This genus appears very heterogeneous, displaying very diverse male forewings (with or without distinct mirror) and male genitalia (elongated and narrow pseudepiphallus as in Burcini, or nemobiini like). Therefore, this genus needs to be reviewed since it most likely includes species belonging to different tribes, and genitalia of Speonemobius type species should be examined to define whether this genus should be kept in Burcini.

Importantly, Speonemobius type species Speonemobius decoloratus Chopard, 1924 has a distinct mirror. This is not the case for Speonemobius alaesignatus Ingrisch, 1987 which has genitalia and forewings corresponding to Paraburcus Gorochov, 2018 (Cigliano et al., 2021). It is worth noting that this species occurs on beaches as other Burcini. We, therefore, propose to temporarily transfer Speonemobius alaesignatus Ingrisch, 1987 to Paraburcus Gorochov, 2018 as Paraburcus alaesignatus (Ingrisch, 1987) n. comb., but this will need confirmation by direct examination of male genitalia.

Speonemobius littoreus has been described from coralline cliffs boarding the sea in Somalia. This species displays the external morphology typical of Burcini. All non-genitalic characters correspond to either Gabusibius n. gen., Malakapobius n. gen., Burcus or Paraburcus. Unfortunately, male genitalia of type and paratype specimens have been destroyed during failed attempts to dissect them (communication by Marco Vannini), but an intact male specimen may still exist in BMNH (not examined). Male FW of $S$. littoreus paratypes appears closer to Gabusibius n. gen., with shorter chords and larger anterior field (Fig. 60). For this reasons, we tentatively propose to place it under this genus as Gabusibius ? litoreus (Vannini \& Chelazzi) n. gen. n. comb.

\section{Discussion}

\section{Number of subapical spurs as a criterion}

The tribe Burcini was originally proposed by Gorochov (1986) to include Nemobiinae crickets with long, narrow and apically bifurcated pseudepiphallus and with 3 outer apical and 3 outer subapical spurs and 2 inner apical and 2 inner subapical spurs. It is worth mentioning that taken alone, the number of subapical spurs may not be a reliable character: some species currently considered as belonging to Speonemobius do not display the characteristically long and narrow pseudepiphallus such as S. decolyi Chopard, 1969 (our observation) whether others like S. alaesignatus Ingrisch, 1987 do display it.

\section{Distribution of Burcini and endemism in coastal Orthoptera in SWIO islands}

Two genera of Burcini are now recorded on SWIO islands, all species here described being single island endemics (Fig. 77). The genus Gabusibius n. gen. occurs on all Comoros with the remarkable exception of Grande Comore whereas the genus Makalapobius n. gen. occurs on both Grande Comore and Mauritius. This distribution with species from Grande Comore and Mauritius morphologically closer to other species from Comoros may appear surprising since 
on SWIO islands, several genera of Orthoptera are endemic at the level of archipelagoes (see for example Hugel, 2012a; Hugel et al., 2021). It is nevertheless not a unique case since similar situation occurs for birds (Foudia and Zosterops) as well as for plants (Begonia) (see discussion in Warren et al. 2013). Various scenarios may account for that peculiar distribution, including multiple dispersal events and even extinctions. The occurrence of Gabusibius n. gen. on Comoros islands of older volcanic origin (Mayotte, Mohéli, Anjouan) and not on Grande Comore may speculatively suggest that ancestors of Gabusibius n. gen. reached Comoros before the emergence of Grande Comore (volcanic origin estimates: 0.5 MYA). Alternatively, an extinction event might have occurred on Grande Comore, the surface of which is made of quite recent lavas (oldest exposed lavas $0.13 \mathrm{MYA}$ ) and harbors an active volcano (see discussion and references for dating in Warren et al. 2013). The lack of Burcini on Grande Comore would speculatively have left a vacant niche for subsequent colonization by ancestors of Malakapobius masihu n. gen. $n$. sp.. Such highly speculative scenarios will be examined by molecular approaches.

All species described in the present manuscript are single-island endemics. This is remarkable for lowland Orthoptera on SWIO islands since most species occurring on coastal SWIO habitats are widespread and not endemic (Hugel, in press). This is for example the case for the crickets Myrmecophilus americanus Saussure, 1877 and Myrmecophilus quadrispina Perkins, 1899, (Hugel and Blard, 2005; Hsu et al. 2020) Trigonidium cicindeloides Rambur, 1839, Natula longipennis (Serville, 1839) (Hugel, 2012b) and Gryllodes sigillatus (Walker, 1869) (Hugel, in press) as well as for the Caelifera Aiolopus thalassinus rodericensis (Butler, 1876) (Parnaudeau et al. 2013; Hugel, 2014) and Xya minor (Chopard, 1920) (Hugel, 2021) among others. Only very few coastal Orthoptera species are single-island-endemics, such as species belonging to the genus Microlandreva Chopard, 1958 on Comoros and Mayotte (SH-LDG, unpublished observations), Mogoplistidae species on Comoros (SH-LDG, unpublished observations) and Mascarene islands (Warren et al. 2016), and the Grasshopper Odontomelus ancestrus Hugel, 2014 on Round Island, an islet North to Mauritius (Hugel, 2014). It has been suggested that this low level of endemism of Orthoptera in SWIO coastal habitats may be a consequence of habitat destruction at low altitude rather than a naturally occurring phenomenon (Hugel, in press).

Importantly, since intertidal habitats are not frequently examined by entomologists, and particularly by Orthopterists, the occurrence of more species of Burcini on SWIO islands is expected, and would deserve targeted surveys.

\section{Threats to Burcini}

Narrow habitat. The habitat of Burcini in South Western Indian Ocean islands, and probably elsewhere, corresponds exclusively to intertidal areas, on the shore or on caves connected to the sea; in New Caledonia these have also been observed along rivers near the sea (LDG, unpublished observations). Although populations of these species can reach very high densities, their very habitat is small, mostly linear, corresponding to a very narrow stripe on the shore. Therefore, tools used to assess threat to these species according to their Extent of Occurrence (EOO) or Area of Occupancy (AOO) (IUCN, 2013) appear poorly adapted.

Siltation. Some of SWIO islands shores tend to silt up with mud as a consequence of deforestation and / or intensive farming practices. Burcini in SWIO seem absent from mudded 
areas and may therefore be indirectly threatened by deforestation (mostly in Comoros) and intensive farming (mostly Mauritius).

Sea level rise. Sea-level rise associated with global warming is a direct threat to these species. Since beaches-backs to be submerged in the next decades are usually artificialized, a shift to equivalent habitats at higher elevation may not be possible. Nevertheless, in a few cases, riverbanks with pebbles might allow a shift to higher elevation.

Modification of beaches for tourism. In SWIO, Burcini do not occur on beaches where all but sand is removed. Removal of pebbles, driftwood and algae from sand beaches makes them unsuitable for Burcini. This tendency to force the shore to fit "postcard" expectations of tourists is mostly an issue in Mauritius where regulations may be needed.

Pollution. The population of Makalapobius aigrettensis $\mathrm{n}$. gen. $\mathrm{n}$. sp. appears to have been directly impacted by the ecological disaster caused in August 2020 by the oil slick following the sinking of the tanker Wakashio. Due to their narrow habitat in the intertidal area, sea water pollution should be considered as a major threat to Burcini.

\section{Acknowledgements}

We thank the national parks and the forestry services of Mauritius, Comoros and Mayotte for giving us access to the protected areas and for logistic support on the field. We are indebted to the numerous colleagues and friends from Mauritius, Comoros and Mayotte, who either helped me directly in the field and/or gave me precious advices and support for my fieldwork. Mauritius: SH thanks the National Parks and the forestry services of Mauritius (National Parks and Conservation Service) for giving access to the protected areas, and the Mauritian Wildlife Fundation (MWF) for logistic support on the field, and particularly Mario Allet (NPCS), Gabriel d'Argent (Mondrain Nature Réserve), Claudia Baider (Mauritius Herbarium), Nik Cole (MWF), Aurelie Chowrimootoo (then at MWF), Sooraj Dwarika (MWF), Vincent Florens (University of Mauritius), Seelavarn Ganeshan (MSIRI), Christine Griffiths (then at MWF), Owen Griffiths (Bioculture), Paul Moolee (NPCS), Ragen Parmananda (NPCS), Kevin Ruhomaun (NPCS), Dominique Strasberg (Université de la Réunion), Vikash Tataya (MWF), Nicolas Zuel (then at MWF), Ben Warren (then at Université de la Réunion). Comoros: Ahmed Ouledi (Univ. des Comores), Ainouddine Sidi (Centre national de Documentation et de Recherche scientifique [CNDRS]), Ramadhoini Ali Islam (Univ. des Comores), Andilyat Mohamed Abdereman (Univ. des Comores), Amissi Said Toihir (Univ. des Comores), Maoulida Abdou (student, Univ. des Comores), Hadidja Sinane (CNDRS), Yahaya Ibrahim (CNDRS), Bourhane Abderemane (CNDRS, Anjouan), Soiffaouiddine Sidi (site Univ. de Patsy, Anjouan), the villagers of Ouallah II (Moheli), Kazouine Moindjie (Ouallah II), Francois Beudard (Parc marin de Moheli), Hugh Doulton (Bristol Conservation and Science Foundation, Anjouan), Cathie Green (Engagement communautaire pour le developpement durable [ECDD] project, Bristol Conservation and Science Foundation, Anjouan), Chaufera Mnamdji (guide, Ngazidja), Oliver Hawlitschek (Zoologische Staatssammlung Munchen), the Consul de France in Moroni and the Vice-Consul de France in Anjouan. Mayotte: Caroline Cremades (Direction de l'Agriculture et de la Foret [DAF] de Mayotte, Service Environnement et Foret), Danny Laybourne (DAF de Mayotte, Service Environnement et Foret), Pierrick Lizot (Conservatoire du littoral), Gildas Le Minter (RN nationale de l'ilot Mbouzi), Guillaume Viscardi (Conservatoire Botanique), Céline Fischer et Florient (Kani-Keli). The field surveys in Mauritius $(2008,2009)$ and Comoros $(4 / 2010)$ have been funded by the BIOTAS project, ANR-06-BDIV-002; the field trip in Comoros in August 
2010 and December 2011 have been funded by the sub-project "Connaître pour conserver: le patrimoine caché des Comores" part of "Biodiversité des îles de l'ocean Indien" funded by Fondation pour la Recherche sur la Biodiversité (FRB, formerly IFB). We thank Dr Luca Bartolozzi (Natural History Museum, University of Florence) for the loan of Speonemobius littoreus paratypes and for having contacted Dr Marco Vannini who is now retired.

\section{References}

Chintauan-Marquier, I.C., Legendre, F., Hugel, S., Robillard, T., Grandcolas, P., Nel, A., Zuccon, D. \& Desutter-Grandcolas, L. (2016) Laying the foundations of evolutionary and systematic studies in crickets (Insecta, Orthoptera): a multilocus phylogenetic analysis. Cladistics, 32: 54-81. https://doi.org/10.1111/cla.12114

Cigliano, M.M., H. Braun, D.C. Eades \& D. Otte. Orthoptera Species File. Version 5.0/5.0. [05/2021]. <http://Orthoptera.SpeciesFile.org>. http://Orthoptera.SpeciesFile.org

Desutter, L. (1987) Structure et évolution du complexe phallique des Gryllidea (Orthoptera) et classification des genres néotropicaux de Grylloidea. 1ère partie. Annales de la Société entomologique de France (N.S.), 23, 213-239.

Desutter-Grandcolas, L. (2003) Phylogeny and the evolution of acoustic communication in extant Ensifera (Insecta, Orthoptera). Zoologica Scripta, 32, 525-561. http://dx.doi.org/10.1046/j.1463-6409.2003.00142.x

Gorochov, A.V. (1986) New and little known crickets (Orthoptera, Gryllidae) from Australia and Oceania. Entomologicheskoe Obozrenie [Revue d'entomologie de l'URSS], 65(4): 692708.

Gorochov, A.V., Tan, M.K. \& Lee, Ch.Ya. (2018) Taxonomic notes on the cricket subfamilies Nemobiinae and Trigonidiinae (Orthoptera: Gryllidae) from islands and coasts of the Pacific and Indian Oceans. Zoosystematica Rossica, 27(2), 290-321. http://10.31610/zsr/2018.27.2.290

Hugel, S. (2012a) New and little known Phisidini from Madagascar, Comoro and Seychelles (Ensifera: Meconematinae). Zoosystema, 34(3): 525-552. http://dx.doi.org/10.5252/z2012n3a3

Hugel, S. (2012b) Trigonidiinae crickets from Rodrigues island: from widespread pantropical species to critically endangered endemic species. Zootaxa, 3191, 41-55. https://doi.org/10.11646/zootaxa.3191.1.4

Hugel, S. (2014) Grasshoppers of the Mascarene Islands: new species and new records (Orthoptera, Caelifera). Zootaxa, 3900(3): 399-414. https://doi.org/10.11646/zootaxa.3900.3.4

Hugel, S. (2021) Présence de Tridactylidae à La Réunion (Orthoptera, Caelifera). Bulletin de la Société Entomologique de France, 126(1): 38-40.

Hugel, S. (In press) Orthoptera. In The new natural history of Madagascar, ed. S. M. Goodman. Princeton, New Jersey: Princeton University Press.

Hugel, S. \& Blard, F. (2005) Présence de grillons du genre Myrmecophilus à l'île de la Réunion (Orthoptera, Myrmecophilinae). Bulletin de la Société Entomologique de France, 110(4/5), 387-389.

Hugel, S., Warren, B.H. \& Desutter-Grandcolas L (submitted) The Phalangopsidae crickets (Orthoptera, Grylloidea) from the Seychelles archipelago: taxonomy of an ecological radiation. Zootaxa, submitted. 
Hsu, P.W., Hugel, S., Wetterer, J.K., Tseng, S.P., Ooi, C.S.M., Lee, C.Y. \& Yang, C.C.S. (2020) Ant crickets (Orthoptera: Myrmecophilidae) associated with the invasive yellow crazy ant Anoplolepis gracilipes (Hymenoptera: Formicidae): evidence for cryptic species and potential co-introduction with hosts. Myrmecological News, 30: 103-129. https://doi.org/10.25849/myrmecol.news_030:103

IUCN (2013) Guidelines for using the IUCN Red List categories and criteria. Version 10.1. Prepared by the Standards and Petitions Subcommittee. http://www.iucnredlist.org/documents/RedList Guidelines.pdf

Jin, X. \& Kevan, D.K.McE. (1992) Taxonomic revision and phylogeny of the tribe Phisidini (Insecta: Grylloptera: Meconematidae). Theses Zoologicae, 18, 1-360.

Otte, D. \& Alexander, R.D. (1983) The Australian crickets. Academy of Natural Sciences of Philadelphia Monograph, 22, 1-477.

Parnaudeau, R., Rochat, J., Franck, A., Gasnier, S., Cazanove, G. \& Hugel S. (2013) Les Acrididae des îles Eparses (Orthoptera, Caelifera). Bulletin de la Société Entomologique de France, 118(1), 111-117.

Rentz, D.C.F. (1985) A monograph of the Tettigoniidae of Australia. Volume 1: The Tettigoniinae. CSIRO, Melbourne, $384 \mathrm{p}$.

Stumpner, A., Dann, A., Schink, M., Gubert, S. \& Hugel, S. (2013) True katydids (Pseudophyllinae) from Guadeloupe: Acoustic signals and functional considerations of song production. Journal of Insect Science 13(157), 1-16.

Vannini, M. \& Chelazzi, G. (1978) Researches on the coast of Somalia. The shore and the dune of Sar Unale. Monitore Zoologico Italiano. Supplemento, 11:1, 1-13, DOI: 10.1080/03749444.1978.10736574

Warren, B.H., Safford, R.J., Strasberg, D. \& Thébaud, C. (2013) Bird biogeography and evolution in the Malagasy region. In Safford, R.J. \& Hawkins, F. eds. The birds of Africa, Vol. 8: the Malagasy Region. London: Christopher Helm, 35-40.

Warren, B.H., Baudin, R., Franck, A., Hugel, S. \& Strasberg, D. (2016) Predicting where a radiation will occur: acoustic and molecular surveys reveal overlooked diversity in Indian Ocean island crickets (Mogoplistinae: Ornebius). PLOS ONE, 11(2): e0148971. doi:10.1371/journal. pone.0148971http://journals. plos.org/plosone/article?id=10.1371/jo urnal.pone.0148971

\section{Legends}

FIGURES 1-8. Makalapobius aigrettensis n. gen. n. sp. 1, Male paratype in dorsal view (specimen 2011MauRod026). 2, same in side view. 3, same, face. 4, same, left hind leg in outer view. 5, same in inner view. 6, same, SGP, flattened. 7, same, right FW, flattened. 8, female paratype (specimen 2011MauRod027): Ovp in left side view (top) and in ventral view (bottom). Scales: 1-2: $10 \mathrm{~mm}$; 3-8: $1 \mathrm{~mm}$.

FIGURES 9-11. Makalapobius aigrettensis n. gen. n. sp. stridulation in natura (specimen BIOTAS2008 424, afternoon, $30^{\circ} \mathrm{C}$; in a cave). 11, power spectrum of 10 .

FIGURES 12-18. Makalapobius masihu n. gen. n. sp. 12, Male holotype in dorsal view. 13, same, face. 14, same, left FIII in outer view. 15, same, SGP, not flattened. 16, same, FW. 17-18, female allotype. 17, Ovp in right side view. 18, body in right side view. Scales: 12: $5 \mathrm{~mm}$; 13-18: $1 \mathrm{~mm}$. 
FIGURES 19-24. Makalapobius n. gen. male genitalia. 19-21, Makalapobius aigrettensis n. gen. n. sp.; Makalapobius masihu n. gen. n. sp. Left panels: dorsal views; middle panel: ventral views; right panels: left side views. Scale: $1 \mathrm{~mm}$.

FIGURES 25-32. Gabusibius ndzilu n. gen. n. sp. 25, Male holotype in dorsal view. 26, same in side view. 27, same, face. 28-29, same, left hind leg in $3 / 4$ and in outer views. 30 , same, SGP, flattened. 31, same, right FW. 32, female allotype: Ovp in left side view (top) and in ventral view (bottom). Scales: 25-26: $10 \mathrm{~mm}$; 27-32: $1 \mathrm{~mm}$.

FIGURES 33-41. Gabusibius mosi n. gen. n. sp. 33, Male holotype in dorsal view. 34, same in left side view. 35, same, face. 36, hind tibia inner view. 37-38, same, left hind leg in $3 / 4$ and in outer views. 39, same, SGP, flattened. 40, same, right FW; flattened. 41, female allotype: Ovp in left side view (top) and in ventral view (bottom). Scales: 33-34: $5 \mathrm{~mm}$; 35-41: $1 \mathrm{~mm}$.

FIGURES 42-48. Gabusibius mosi n. gen. n. sp., stridulation in Mohéli, Miremani, 10h a.m.; $25^{\circ} \mathrm{C}$. 42 , full sequence with several specimens singing. 43-48; details of the sequence. 45 , power spectrum of 44.48 , power spectrum of 47 .

FIGURES 49-56. Gabusibius dzindzanu n. gen. n. sp. 49-50, Male holotype in dorsal view (49) and left side view (50). 51, same, face. 52, hind leg outer view. 53, hind leg inner view. 54, same, SGP, flattened. 55, same, right FW; flattened. 56, female allotype: Ovp in left side view (top) and in ventral view (bottom). Scales: 49-50: $10 \mathrm{~mm}$; 51-56: $1 \mathrm{~mm}$.

FIGURES 57-61. G. ? litoreus (Vannini \& Chelazzi, 1978) n. gen. n. comb. paratypes. 57-58, male in right side view (57) and dorsal view (58). 59, same, face. 60, right FW, flattened. 61, Ovp in left side view (top) and ventral view (bottom).

FIGURES 62-70. Male genitalia of Gabusibius n. gen. 62-64, Gabusibius ndzilu n. gen. n. sp. 6567, Gabusibius mosi n. gen. n. sp.; 68-70, Gabusibius dzindzanu n. gen. n. sp. Left panels: dorsal views; middle panel: ventral views; right panels: left side views. Scale: $1 \mathrm{~mm}$.

FIGURES 71-76. Makalapobius n. gen. (71-72) and Gabusibius n. gen. (73-76) in natura. 71-72, Makalapobius aigrettensis n. gen. n. sp. 73-74, Gabusibius mosi n. gen. n. sp. 75-76, Gabusibius dzindzanu n. gen. n. sp. Left panels are males, right panels are females.

FIGURE 77. Distribution of Makalapobius n. gen. and Gabusibius n. gen. in South Western Indian Ocean. 


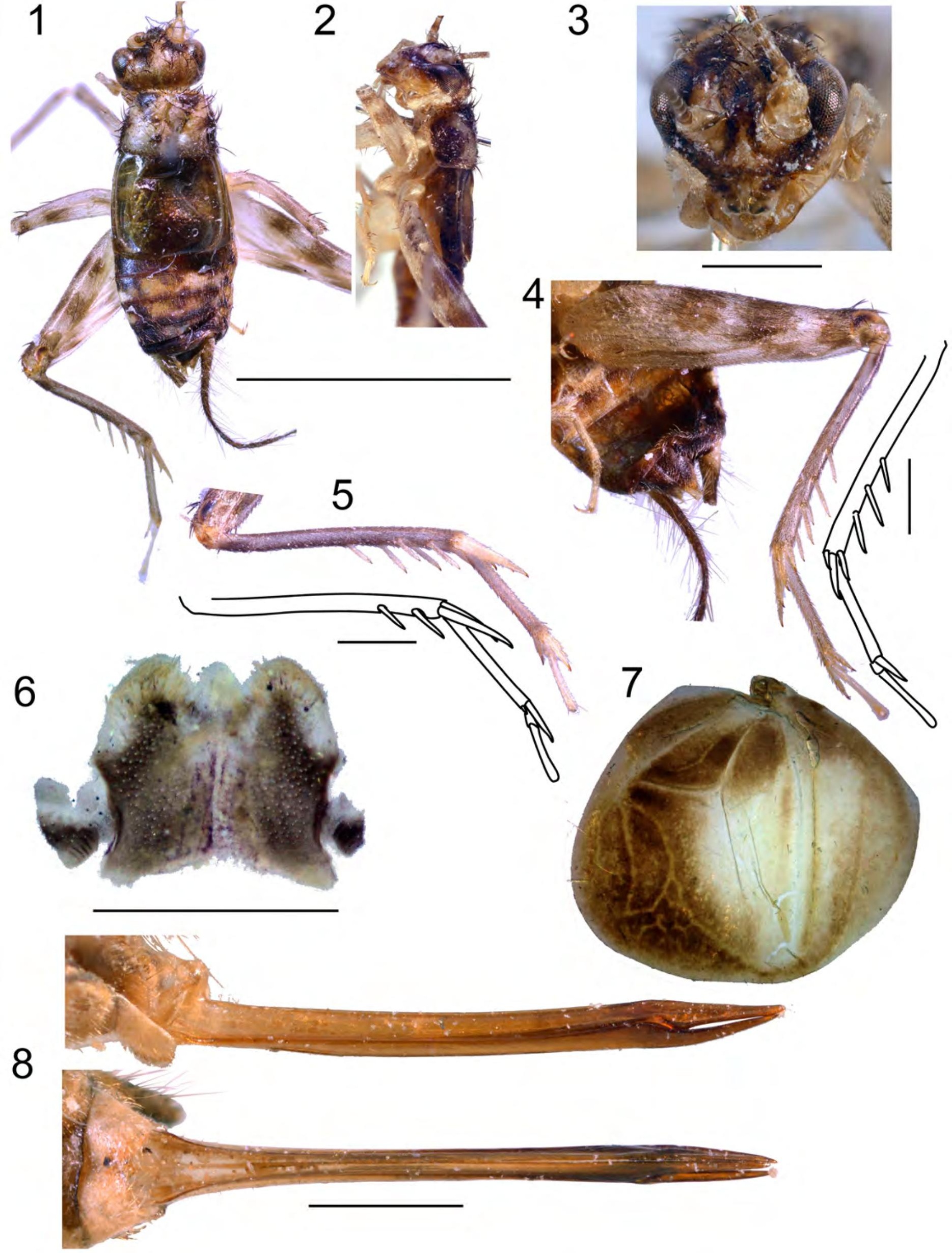




\section{9}
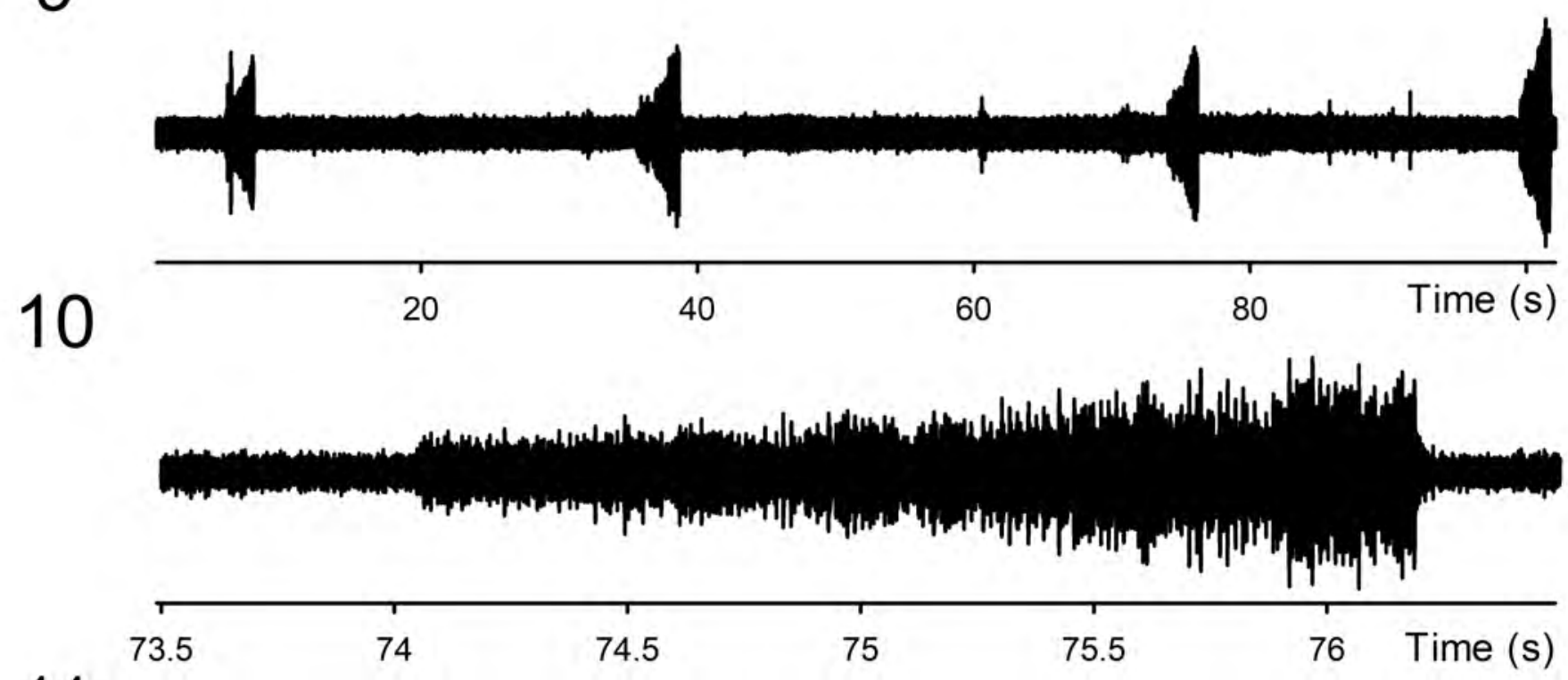

11

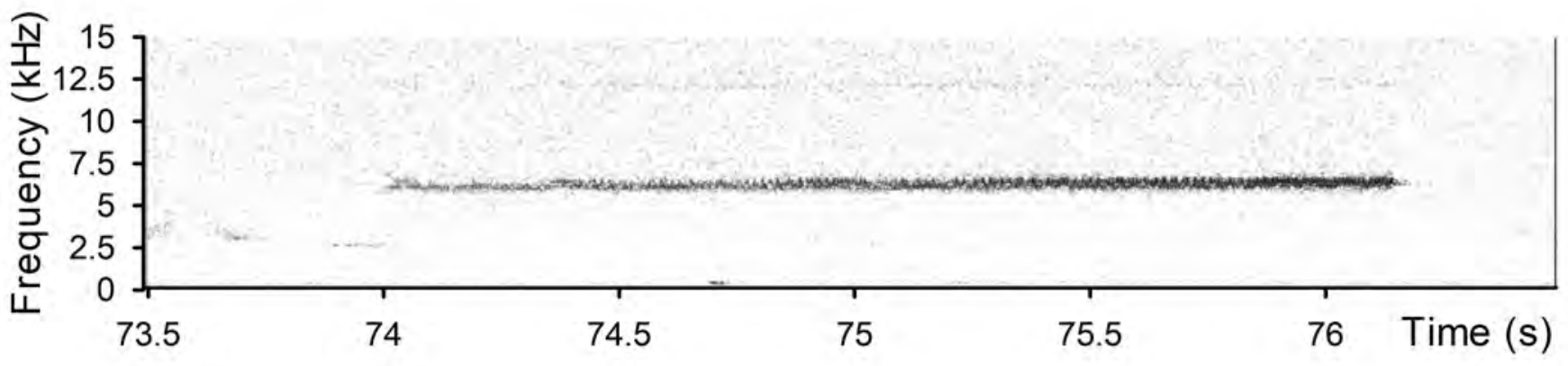




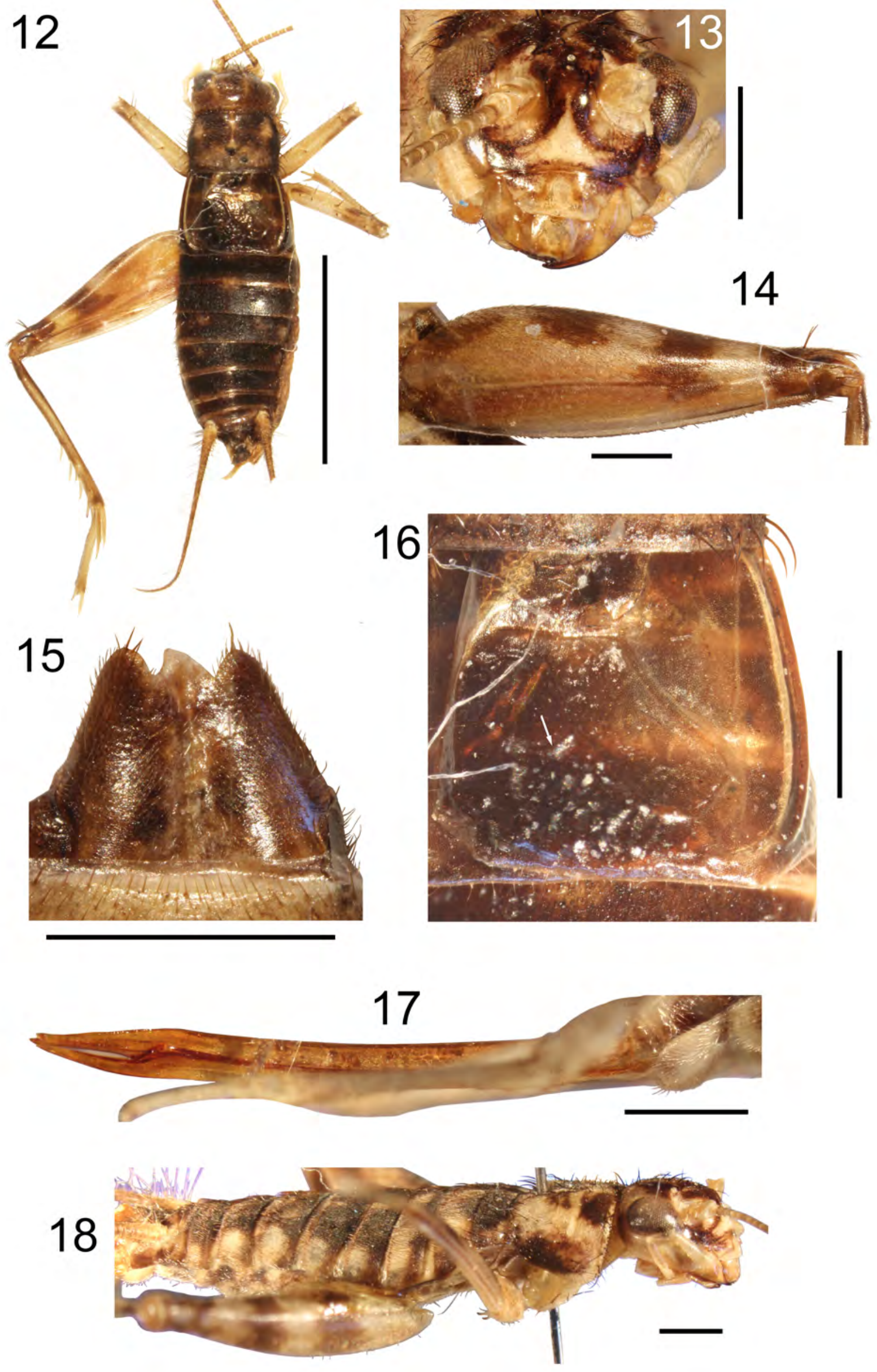




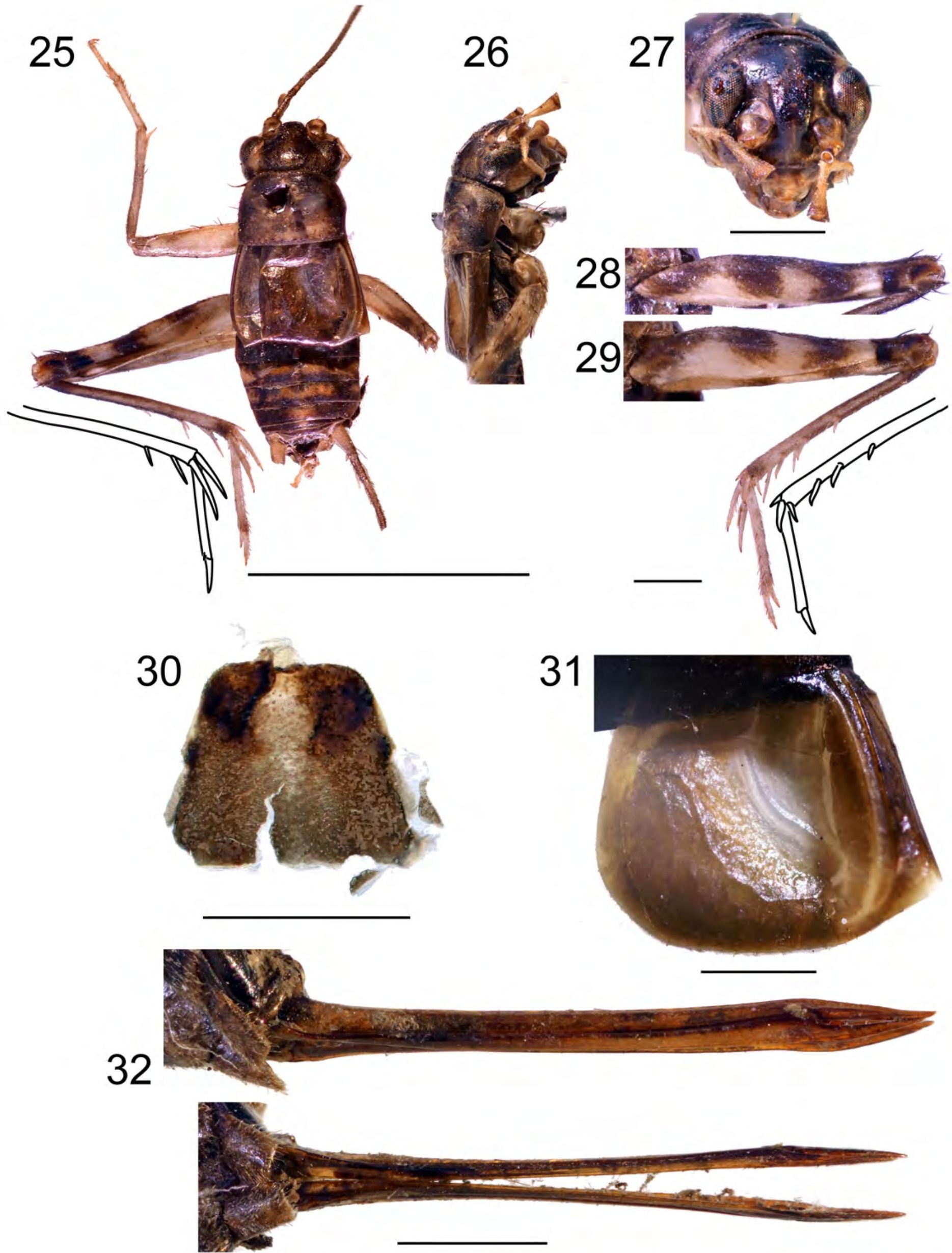



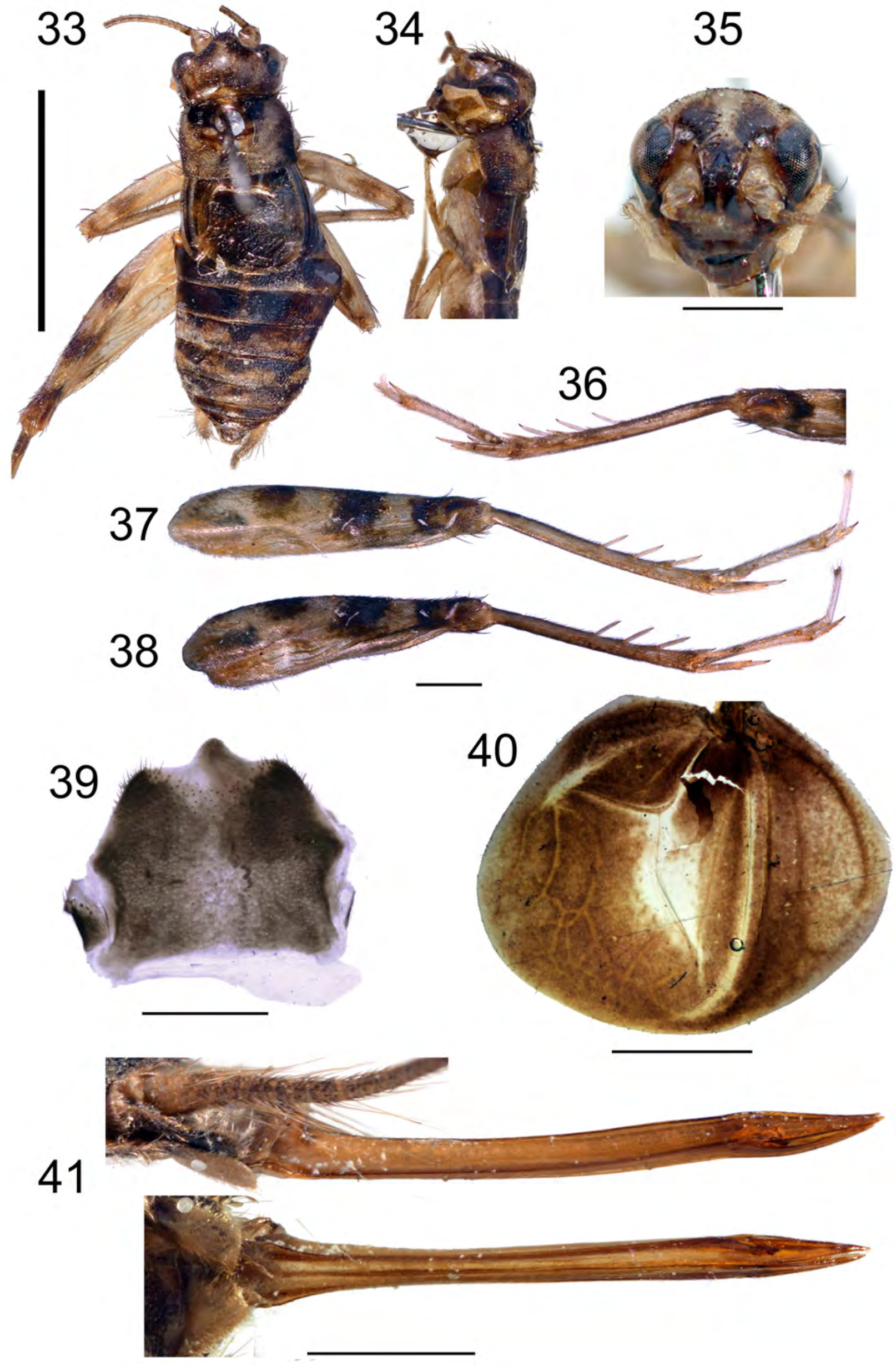


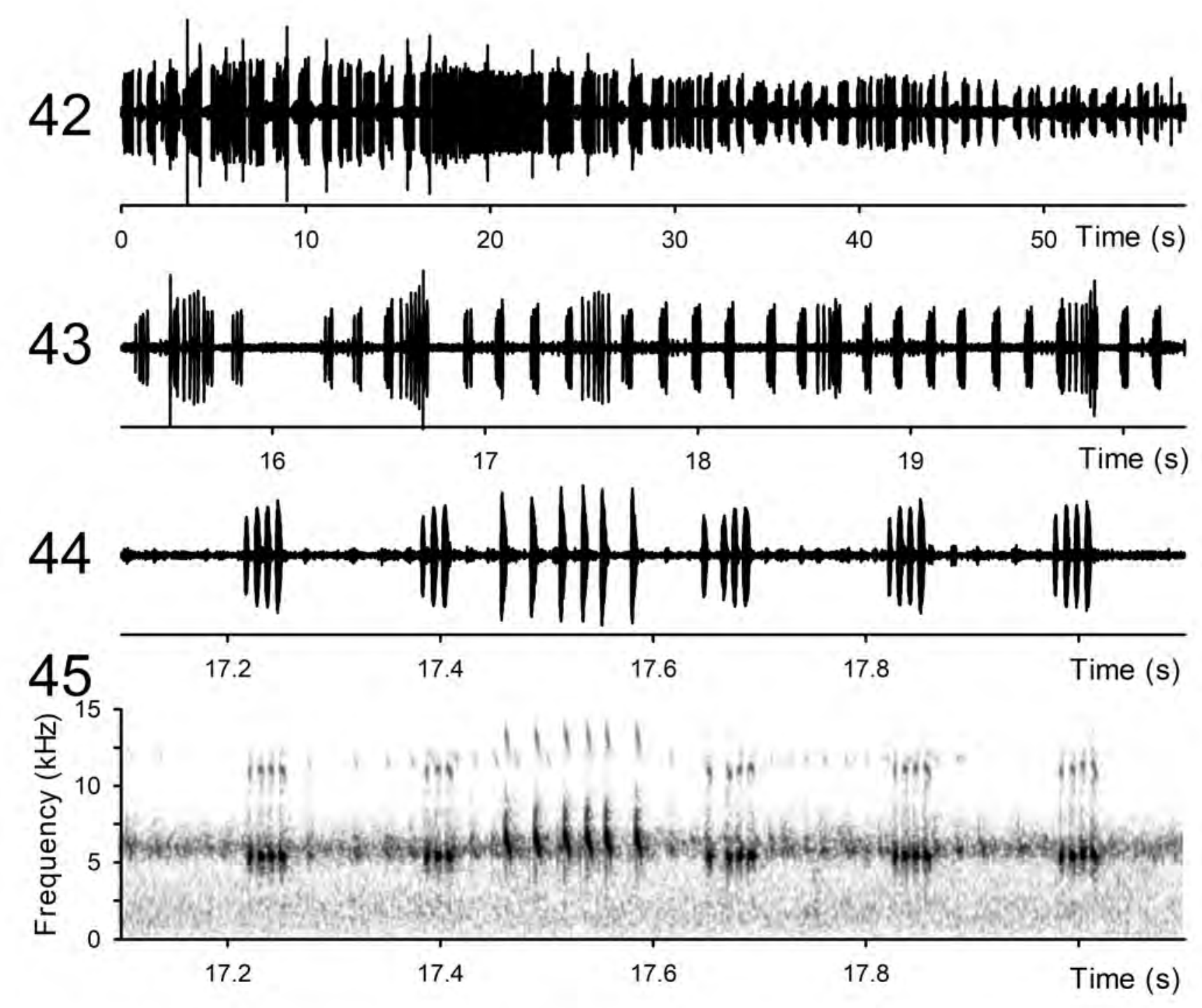

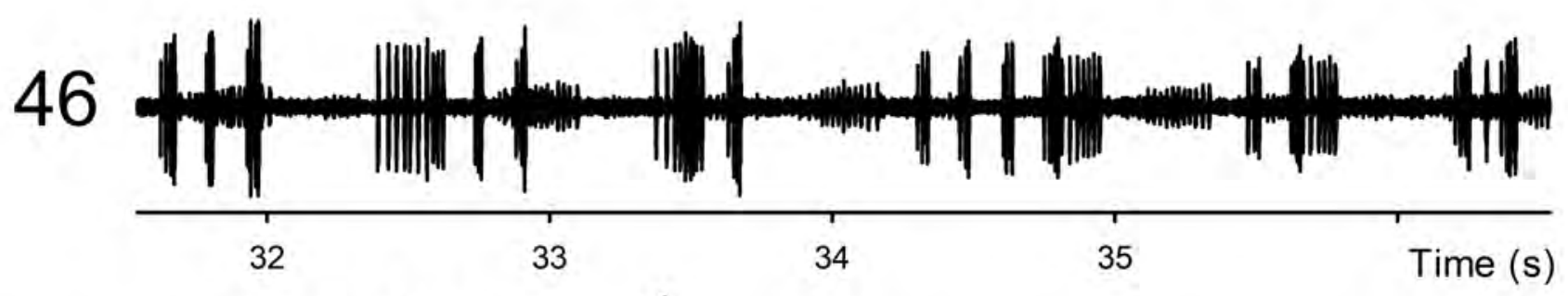
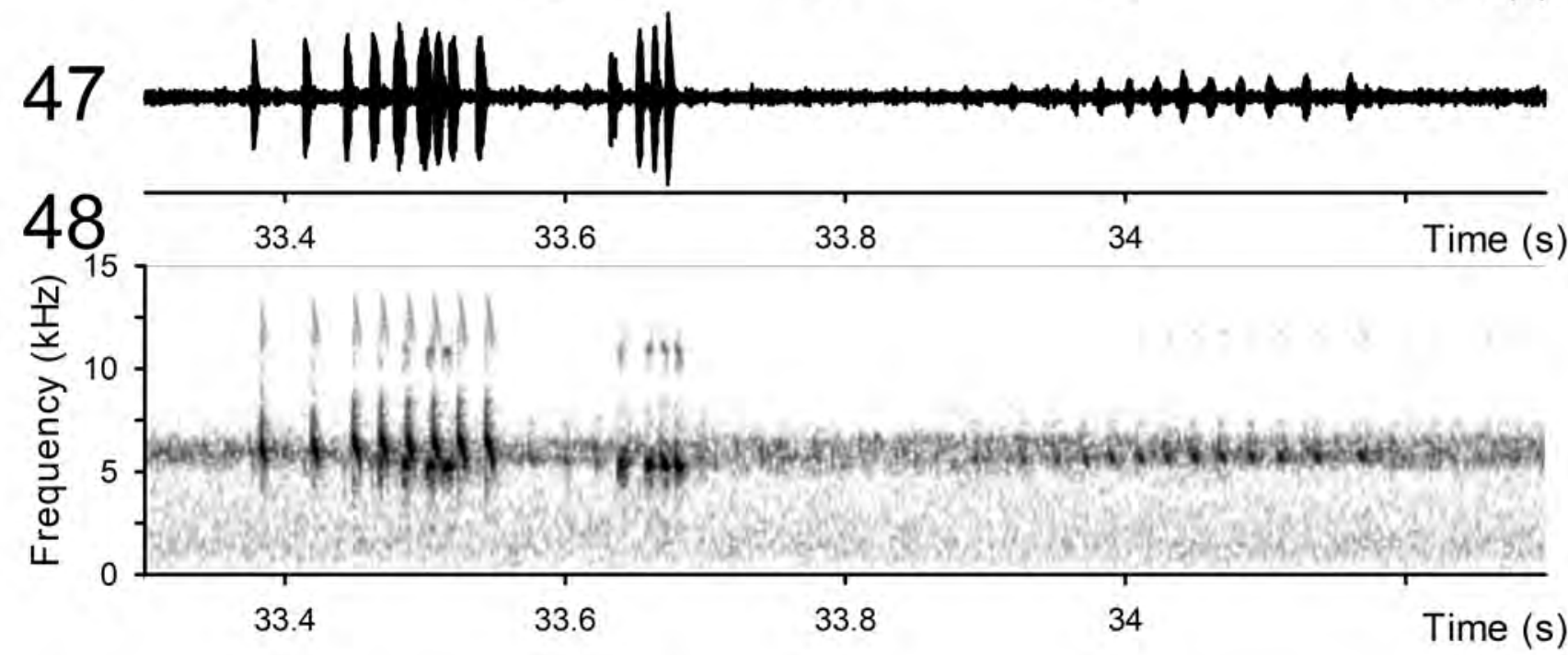


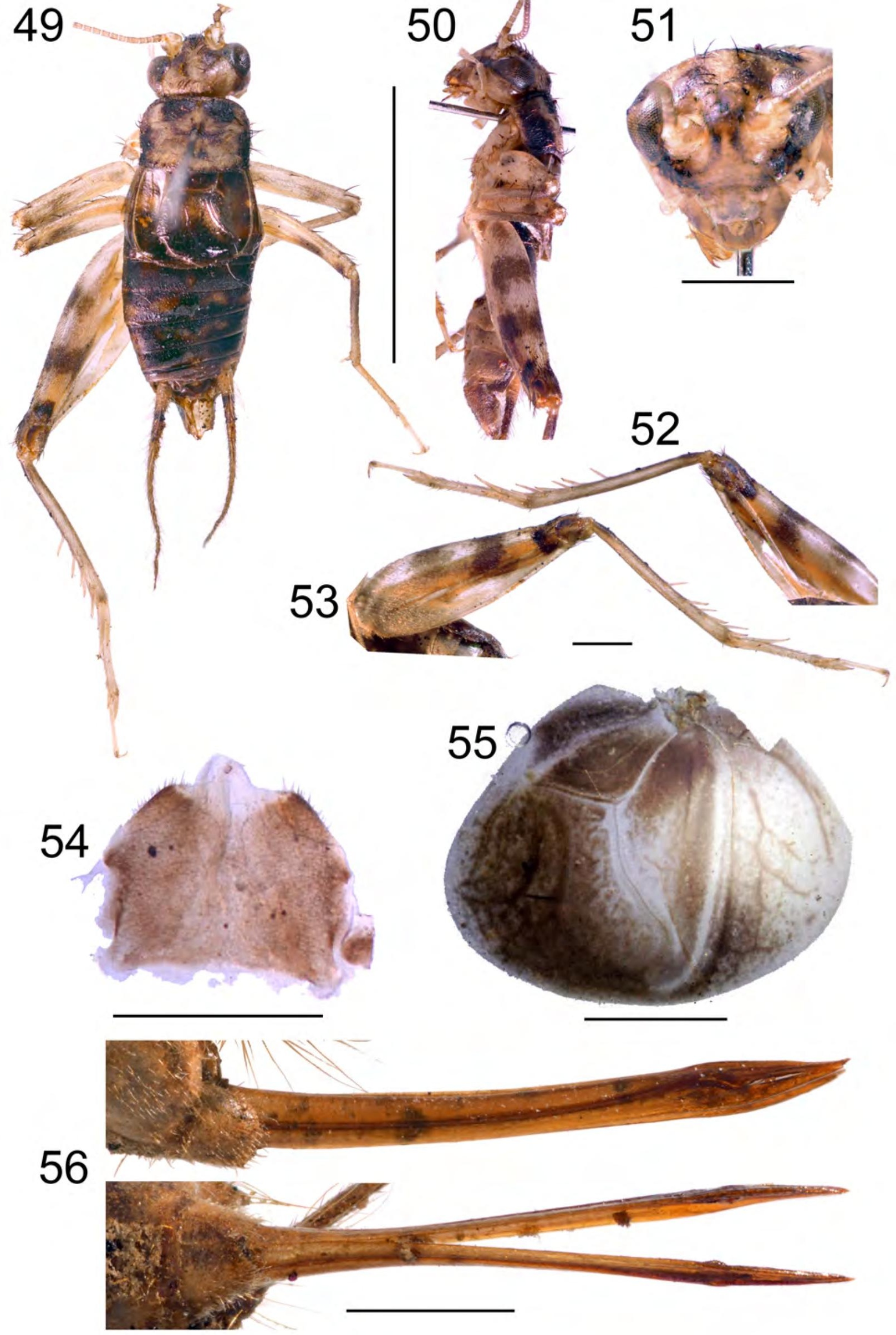




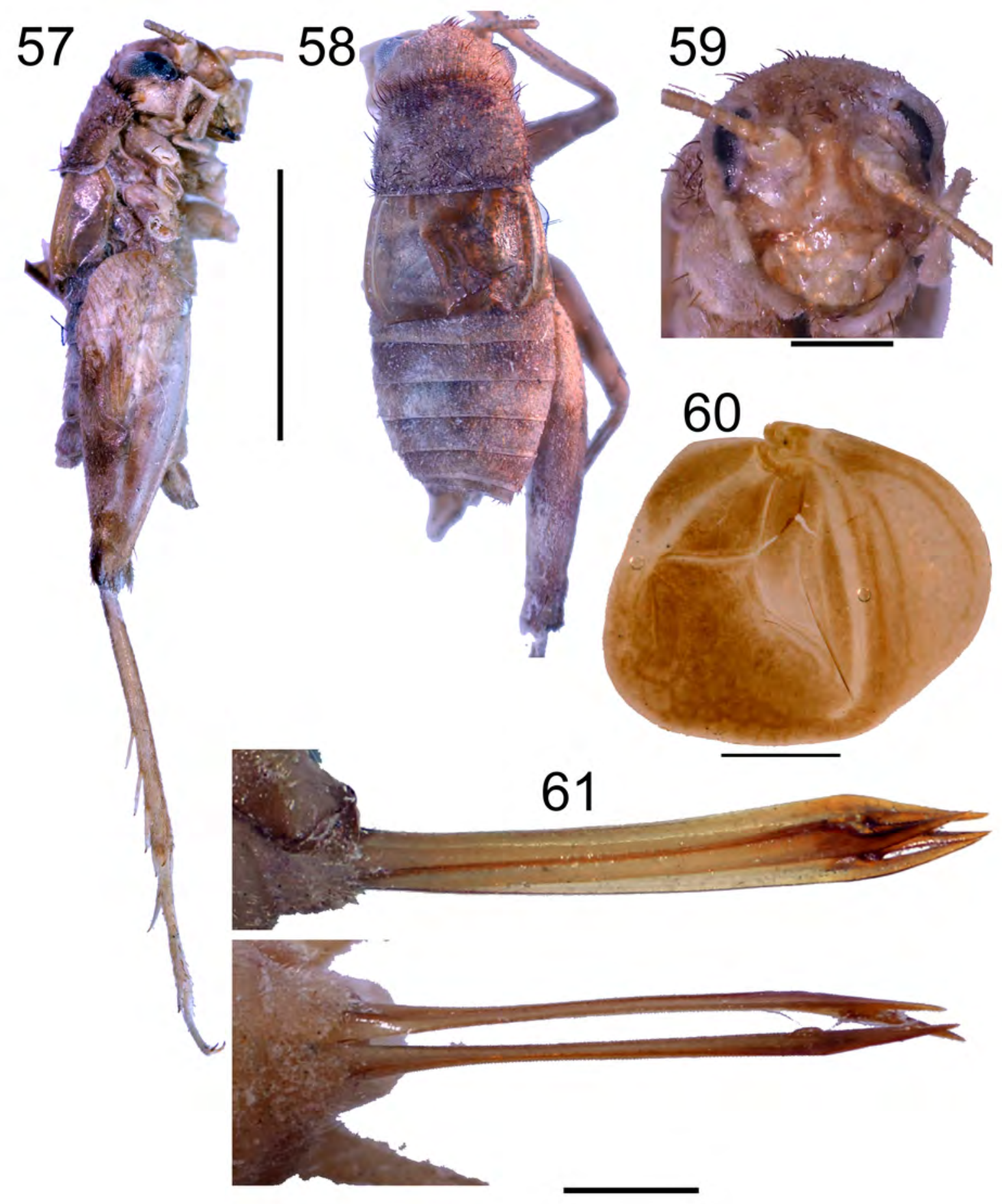




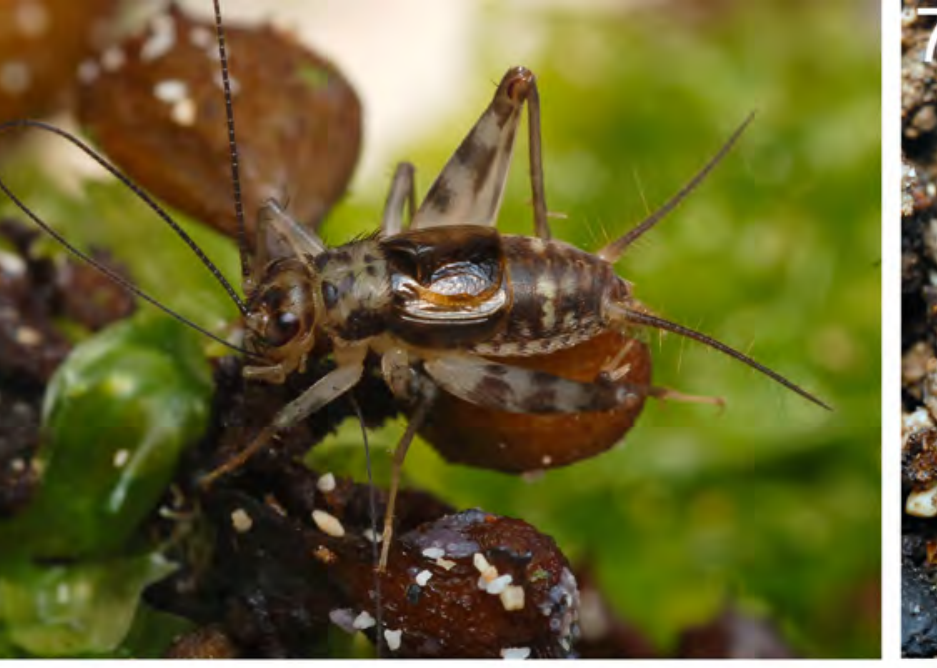

$72(-15 \mathrm{x}-\mathrm{x}$ (

ton

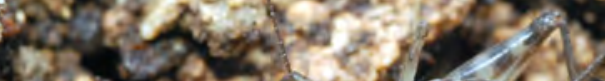

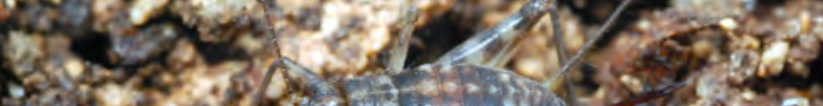

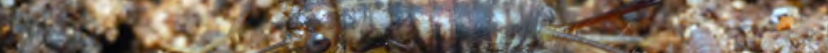

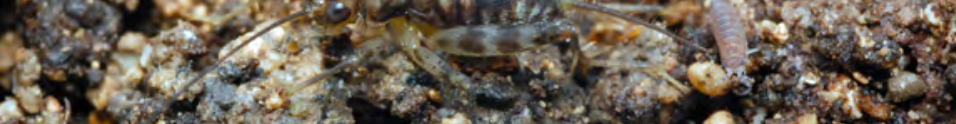

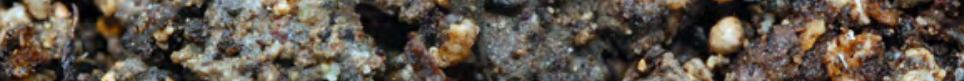

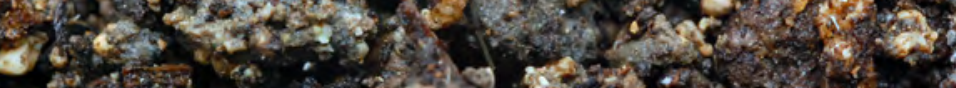

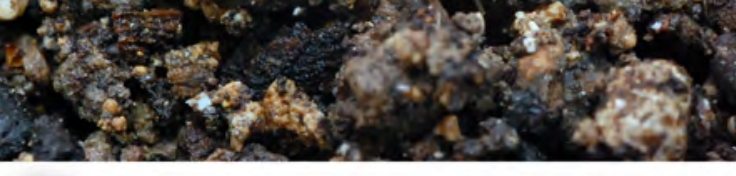

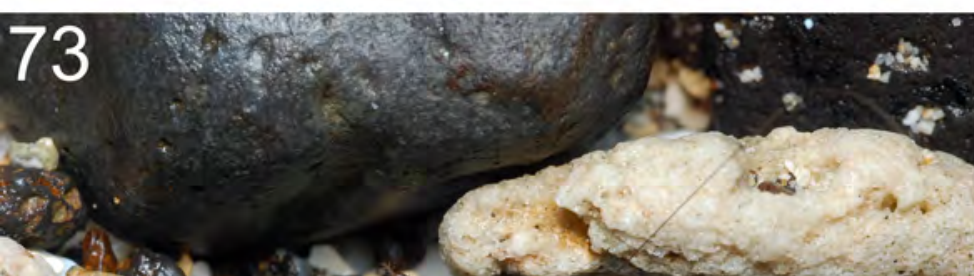

$48+4,2$,
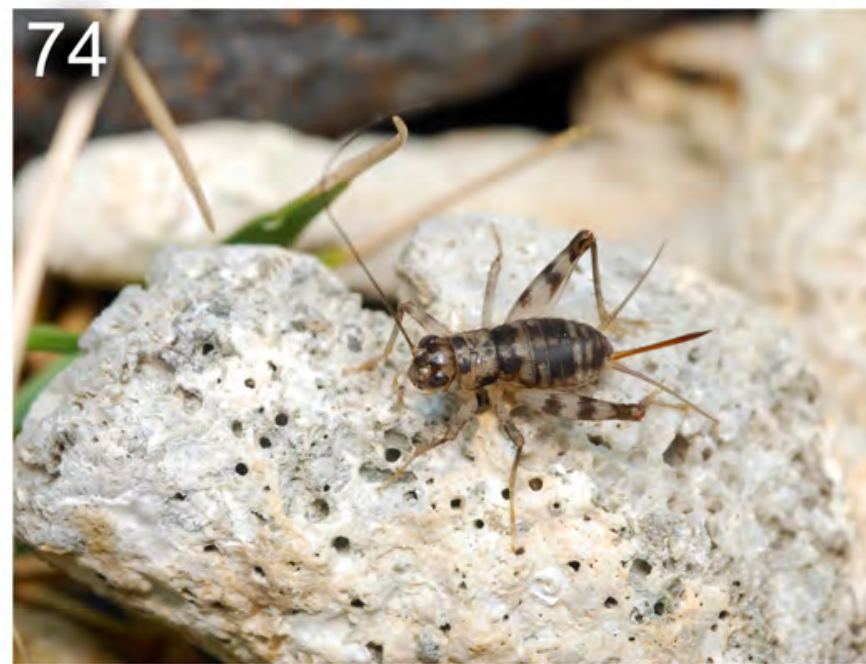

\section{5}
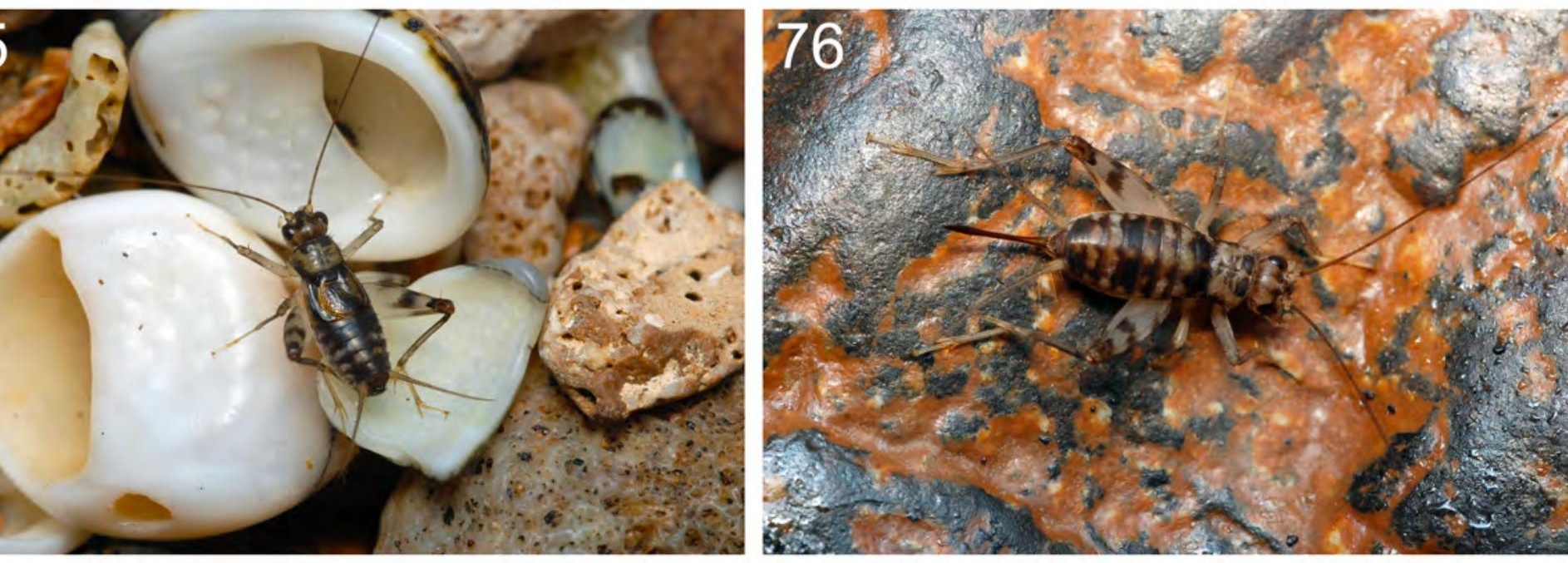
AFRICA

\section{7}

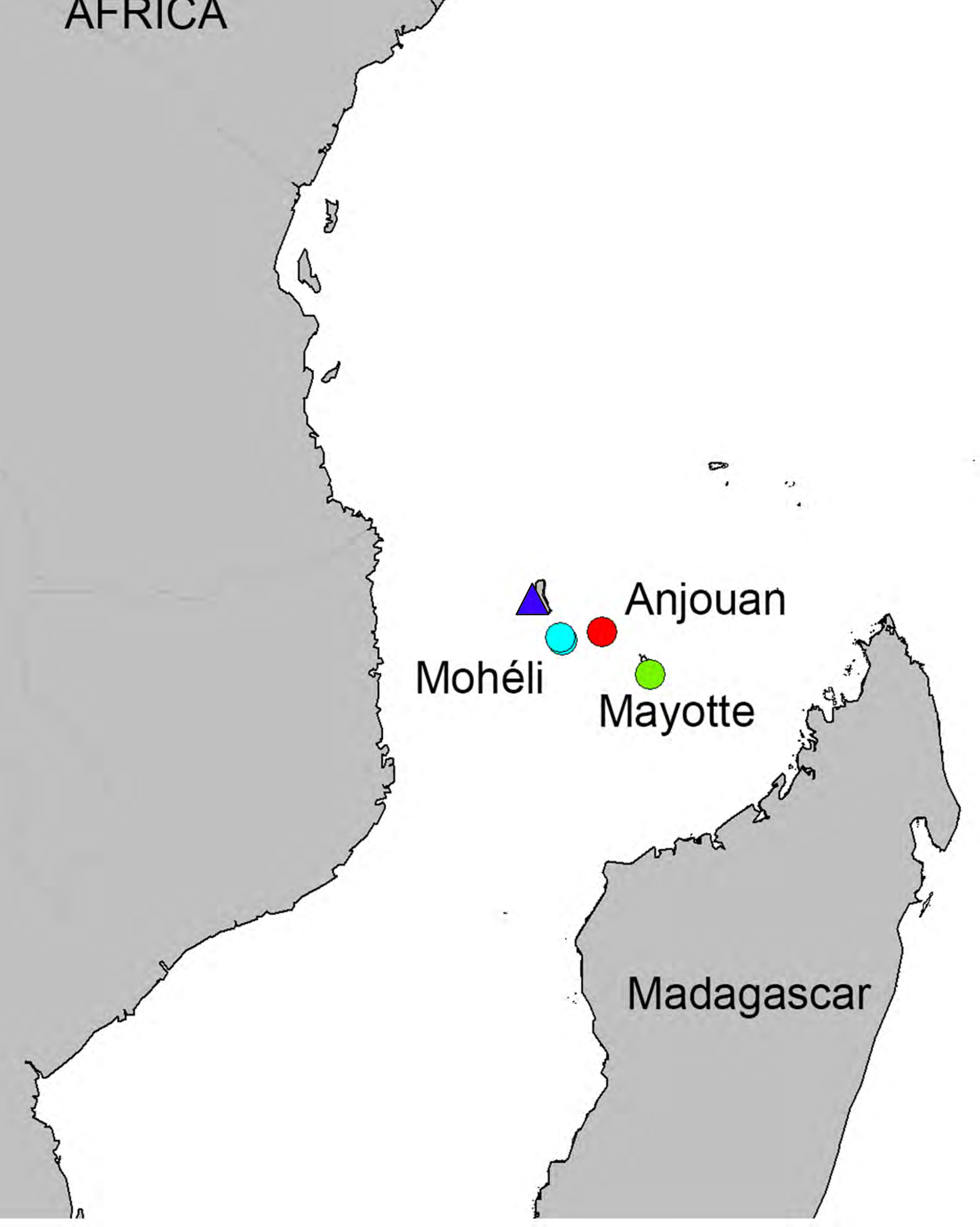

Mauritius

\section{la Réunion}

$\triangle$ Makalapobius aigrettensis n. gen. n. sp.

$\triangle$ Makalapobius masihu n.gen. n. sp.

Gabusibius mosi n. gen. n. sp.

Gabusibius ndzilu n. gen. n. sp.

Gabusibius dzindzanu n. gen. n. sp.

Gabusibius ? litoreus

(Vannini \& Chelazzi, 1978) n. gen. n. comb. 